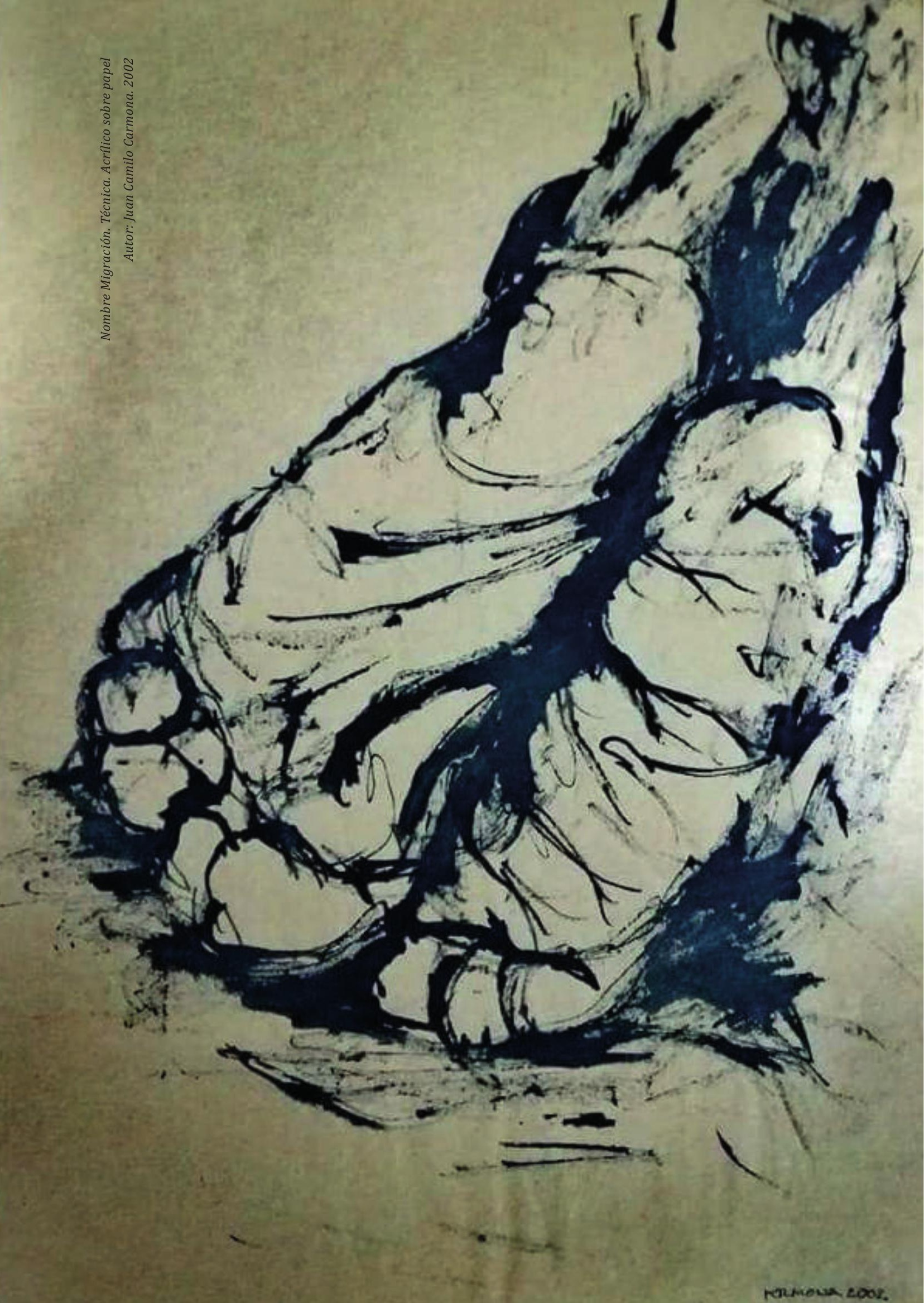




\title{
Amparo universal de los derechos de los migrantes. Marco comparativo y convencional de protección
}

\author{
Enrique Gil Botero*
}

* Exministro de Justiciay del Derecho de Colombia, Colombia. Exconsejero de Estado. Excomisionado dela Comisión Interameri- cana de Derechos Humanos - CIDH. Abogado egresado de la Universidad de Antioquia. ORCID: 0000$0002-4645-2649$ 


\section{Lecciones}

\section{Amparo universal de los derechos de los migrantes. Marco comparativo y convencional de protección}

En este texto se describen, en primer lugar, algunas de las principales dinámicas y situaciones de las crisis migratorias que se han venido evidenciando en la región durante los últimos años, así como también algunos elementos comunes a estas crisis. Posteriormente, se aborda el tema del debido proceso en el ejercicio de la política y el control migratorio y los estándares internacionales del procedimiento de determinación de la condición de refugiado. Finalmente, a partir de algunos de los principales casos que han sido resueltos por los órganos del Sistema Interamericano de Derechos Humanos -la Comisión y la Corte- y por el Tribunal Europeo de Derechos Humanos, se muestran las contribuciones que se han generado en el desarrollo de estándares tendientes a garantizar los derechos humanos de las personas migrantes y otras en el contexto de la movilidad humana.

\section{Generalidades}

Para 2015, se estimaba el número de migrantes internacionales en 244 millones de personas a nivel mundial, lo cual representa un 3.3\% de la población. Del total de migrantes internacionales en el mundo, en las américas hay 63 millones; o sea que el $26 \%$ de migrantes internacionales a nivel mundial se encuentra en América. De 65.3 millones de personas desplazadas forzosamente en todo el mundo, 40.8 millones eran personas desplazadas internas ${ }^{1}$, 21.3 millones

1 Los Principios Rectores de los desplazamientos internos definen como "desplazados internos" a las personas o grupos de personas que han sido forzados u obligados a huir de sus hogares o lugares de residencia habitual, o a abandonarlos, en particular a causa de un conflicto armado, de situaciones de violencia generalizada, de violaciones de los derechos humanos o desastres naturales o causados por el ser humano, y que aún no han cruzado una frontera estatal internacionalmente reconocida.

Dentro de la definición de desplazados internos que dan los Principios Rectores, la utilización de la expresión "en particular" significa que no se trata de un listado exhaustivo, sino que también pueden haber otras causas posibles de desplazamiento interno, tal como pueden ser los proyectos de desarrollo a gran escala, que no estén justificados 
eran refugiados ${ }^{2}$, 3.2 millones eran solicitantes de asilo ${ }^{3}$. Esta es la mayor cifra de personas desplazadas forzosamente desde la Segunda Guerra Mundial.

La mayor parte de los titulares y de la atención internacional con relación a las crisis migratorias y de refugiados se han centrado en lo que ha venido sucediendo en Europa, Siria e Irak durante los últimos años; e igualmente en Centroamérica. Cabe recordar las trágicas imágenes del pequeño niño sirio Alan Kurdi, quien a principios de septiembre del 2015 yacía inerte en una playa de Turquía, después del naufragio de la embarcación en la que se trasladaba junto con sus padres y su hermano mayor, cuando intentaban atravesar el Mar Mediterráneo para buscar protección en Europa. La imagen de este niño volcó la atención mundial hacía Siria y los riesgos que toman miles de refugiados que intentan llegar a Europa en busca de protección. Sin embargo, olvidamos pronto; como si estuviéramos anestesiados moralmente frente al dolor de nuestros semejantes, todos integrantes de una sola familia: la humanidad. Alan Kurdi, su madre y su hermano hicieron parte de esas 3702 personas que fallecieron en el Mediterráneo cuando intentaban llegar a Europa para aquel entonces.

por un interés público superior o primordial. Los proyectos de desarrollo a gran escala se mencionan en el Principio 6, relativo a casos de desplazamiento arbitrario. Véase, Naciones Unidas, Comisión de Derechos Humanos, Informe del Representante del Secretario General, señor Francis M. Deng, presentado con arreglo a la Resolución 1997/39. Adición: Principios Rectores de los Desplazamientos Internos. 11 de febrero de 1998, E/CN.4/1998/53/Add.2, Principio 6.

2 De acuerdo con el artículo 1 de la Convención sobre el Estatuto de los Refugiados de 1951, modificada por el Protocolo sobre el Estatuto de los Refugiados de 1967, el término "refugiado" hace relación a la persona que debido a fundados temores de ser perseguida por motivos de raza, religión, nacionalidad, pertenencia a determinado grupo social u opiniones políticas, se encuentra fuera del país de su nacionalidad; o que, careciendo de nacionalidad y hallándose fuera del país donde tuviera su residencia habitual, no pueda o, a causa de dichos temores, no quiera regresar a él.

Tomando en cuenta las particularidades de la región, la Declaración de Cartagena sobre Refugiados de 1984 amplió la definición de refugiados contenida en la Convención sobre el Estatuto de los Refugiados de 1951. En este sentido, la Declaración establece que: “(...) en vista de la experiencia recogida con motivo de la afluencia masiva de refugiados en el área centroamericana, se hace necesario encarar la extensión del concepto de refugiado, teniendo en cuenta, en lo pertinente, y dentro de las características de la situación existente en la región, el precedente de la Convención de la Organización de la Unidad Africana (OUA) (artículo 1, párrafo 2) y la doctrina utilizada en los informes de la Comisión Interamericana. De este modo, la definición o concepto de refugiado recomendable para su utilización en la región es aquella que además de contener los elementos de la Convención de 1951 y el Protocolo de 1967, considere también como refugiados a las personas que han huido de sus países porque su vida, seguridad o libertad han sido amenazadas por la violencia generalizada, la agresión extranjera, los conflictos internos, la violación masiva de los derechos humanos u otras circunstancias que hayan perturbado gravemente el orden público" (Declaración de Cartagena sobre Refugiados, 1984).

Al respecto, la Corte Interamericana en su Opinión Consultiva OC-21/14, relativa a los "Derechos y garantías de niñas y niños en el contexto de la migración y/o en necesidad de protección internacional", sostuvo que en atención al desarrollo progresivo del derecho internacional, las obligaciones derivadas del derecho a buscar y recibir asilo resultan operativas respecto de aquellas personas que reúnan los componentes de la definición ampliada de la Declaración de Cartagena sobre Refugiados de 1984, la cual responde no solo a las dinámicas de desplazamiento forzado que la originaron, sino que también satisface los desafíos de protección que derivan de otros patrones de desplazamiento que suceden en la actualidad. Este criterio refleja una tendencia a consolidar en la región una definición más incluyente que debe ser tomada en cuenta por los Estados a fin de otorgar la protección como refugiado a personas cuya necesidad de protección internacional es evidente.

3 El término "solicitante de asilo" hace relación a la persona que solicita el reconocimiento de la condición de refugiado y cuya solicitud todavía no ha sido evaluada en forma definitiva en el país de acogida. 
A pesar de lo anterior, las respuestas que muchos Estados vienen dando frente a crisis migratorias son claramente violatorias de derechos humanos o sino, por lo menos, ponen a los migrantes y refugiados en grave riesgo de violaciones a sus derechos. Lamentablemente, aún estamos muy lejos de asegurar a las personas migrantes esa premisa fundamental de los derechos humanos como "derechos iguales e inalienables de todos los miembros de la familia humana" (Asamblea General de la ONU, 1948). Tal como ha sostenido Stefanie Grant (2011), durante gran parte del tiempo que ha transcurrido desde la adopción de la Declaración Universal de Derechos Humanos de 1948, "los migrantes han estado en los márgenes del derecho internacional de los derechos humanos, atrapados entre los principios de universalidad y reglas excluyentes de la soberanía estatal y la legislación nacional" (p.25).

Ahora bien, la problemática de Europa que se ha visibilizado más, ha impedido que tomemos consciencia de que en el continente americano también está ocurriendo una crisis de proporciones mayúsculas, en la que miles de personas, que proceden en su mayoría de los países del Triángulo Norte de Centroamérica, así como de México, Haití y Cuba, recorren un sinuoso camino por vías clandestinas para llegar a los Estados Unidos y se exponen a toda clase de peligros e incluso se someten a delitos tan graves como la violencia sexual y a atentados contra su vida e integridad física. De igual forma, no puede perderse de vista la crisis migratoria que persiste entre los países de Haití y República Dominicana, país este último que ha diseñado una serie de políticas para evitar la entrada de haitianos a su territorio, las cuales han estado marcadas por prejuicios de tipo racial y que han traído como consecuencia el estado de apátrida para un gran número de dominicanos de ascendencia haitiana.

En años recientes se ha evidenciado un incremento significativo en la migración forzada de personas en México y los países del Triángulo Norte (El Salvador, Guatemala y Honduras) a causa de la violencia del crimen organizado (maras y carteles del narcotráfico) y los desastres naturales asociados con los efectos del cambio climático. Estos factores suelen estar ligados a otros factores generadores de migración forzada que han estado presentes a lo largo de la historia de la región, tales como la desigualdad, la pobreza y los conflictos armados.

Una de las principales formas y consecuencias de la violencia que han experimentado estos países ha sido la migración forzada de cientos de miles de personas tanto dentro del territorio de dichos Estados, así como hacía otros países de la región.

De 2010 a 2015, el número de solicitantes de asilo de estos países incrementó en un $832 \%$, mientras que el de refugiados incrementó en un $130 \%$.

La tasa de personas que son reconocidas como refugiadas sigue siendo baja en comparación con el número de solicitantes de asilo. Solo 1, de cada 4 personas que podrían tener necesidades protección internacional, logra ser reconocido 
como refugiado. La tendencia en materia de solicitudes de asilo es principalmente regional. La mayoría de las personas que huyen de Centroamérica y México solicitan asilo en los Estados Unidos y, en menor medida, en otros países vecinos tales como Costa Rica, Belice, Panamá y Nicaragua. La mayoría de estos refugiados se encuentran en áreas urbanas y periurbanas, sin acceso a ningún tipo de asistencia humanitaria.

En adición a lo anterior, la región también ha sido testigo de otras crisis migratorias. Por ejemplo, toda la migración forzada que se ha generado como consecuencia del conflicto armado y de otras formas de violencia asociadas a éste como en Colombia, las cuales según el Registro Único de Víctimas del Estado colombiano han ocasionado el desplazamiento interno de cerca de 7 millones de personas, lo que hace de Colombia el país con el mayor número de desplazados internos a nivel mundial, incluso superando a Siria. La violencia asociada al conflicto armado en Colombia también ha ocasionado la migración forzada transfronteriza de más de 350.000 refugiados colombianos a otros países (ACNUR, 2016).

Otro ejemplo reciente de una crisis migratoria en la región tiene que ver con la crisis humanitaria que se generó a partir de la decisión del presidente de Venezuela, Nicolás Maduro, de cerrar la frontera con Colombia el 19 de agosto de 2015. Estas medidas tuvieron como resultado la expulsión colectiva de 1950 colombianos que vivían en situación migratoria irregular en Venezuela en cuestión de un par de días.

Hoy hay en Colombia 1.032.016 venezolanos (Migración Colombia, 2018), de los cuales 573.502 son regulares (con Visa, Cédula de Extranjería, PEP o Dentro del Tiempo de Ley Establecido), 240.416 están en proceso de regularización (se censaron en el RAMV y están pendientes de la expedición del PEP) y 218.098 son irregulares (137.718 que superaron el tiempo de permanencia y quedaron en condición irregular y 80.380 que ingresaron por pasos no autorizados o trochas).

Como constantes de estas recientes situaciones de crisis migratorias se pueden colegir algunos elementos tales como:

a. suelen afectar números muy significativos de personas, que pueden contarse desde cientos hasta millones;

b. por lo general, ocurren en lugares aislados como fronteras o apartadas rutas migratorias, lo cual aumenta la vulnerabilidad de las personas migrantes a ser víctimas de abusos y violaciones a sus derechos humanos por parte de delincuentes, pero también de autoridades estatales;

c. en lo que respecta a su duración, algunas de estas crisis suelen ser resueltas de forma sumaria, pero también se dan algunas situaciones de crisis prolongadas que pueden durar meses o incluso años; 
d. las autoridades suelen actuar con alto grado de discrecionalidad y arbitrariedad en el uso de medidas tales como redadas migratorias, detenciones y expulsiones sumarias o colectivas;

e. la coordinación entre Estados suelen darse más para implementar medidas de contención migratoria, tales como interceptaciones y mayores controles de seguridad y militarización de las fronteras; y

f. el cúmulo de los factores anteriores, así como la falta de conocimiento del idioma o del sistema legal y la falta de asistencia legal, ocasionan que la mayoría de las violaciones a los derechos humanos de los migrantes queden en la impunidad y que estas personas no tengan acceso a un recurso judicial efectivo ni a reparación integral.

En muchos casos estas personas se han visto forzadas a migrar porque las condiciones de violencia los han obligado a ello o porque situaciones de pobreza extrema y de escasez de alimentos y medicamentos les han forzado y sin embargo las respuestas que suelen encontrar son obstáculos por parte de los Estados para ejercer su derecho humano a salir libremente del territorio del que son nacionales, o incluso su derecho a solicitar y recibir asilo.

Es una vergüenza que gran parte de las respuestas que están dando los Estados para personas que vienen huyendo de contextos de violencia sea ponerles en detención migratoria de forma automática, incluso tratándose de niñas y niños, con todo el grave impacto que esto tiene para su salud física y mental. Incluso, es aún peor, que muchas de estas personas sean deportadas de forma sumaria a países en donde sus vidas están en riesgo. Una humillación a la civilidad, a la historia, al progreso y a la dignidad del ser humano.

Si bien los procesos migratorios han sido inherentes al desarrollo económico y social de la humanidad, y en algún momento fueron percibidos como algo positivo, hoy en día los inmigrantes son vistos como un problema y una amenaza por los países receptores, lo cual los hace blanco de estigmas, estereotipos y prácticas xenófobas que acentúan aún más la situación de vulnerabilidad en que se encuentran ${ }^{4}$. Es decir, además de la condición de desarraigo a la que se enfren-

4 “112. Generalmente los migrantes se encuentran en situación de vulnerabilidad como sujetos de derechos humanos, en una condición individual de ausencia o diferencia de poder con respecto a los no-migrantes (nacionales o residentes). Esta condición de vulnerabilidad tiene una dimensión ideológica y se presenta en un contexto histórico que es distinto para cada Estado, y es mantenida por situaciones de jure (desigualdades entre nacionales y extranjeros en la leyes) y de facto (desigualdades estructurales). Esta situación conduce al establecimiento de diferencias en el acceso de unos y otros a los recursos públicos administrados por el Estado.

“113. Existen también prejuicios culturales acerca de los migrantes, que permiten la reproducción de las condiciones de vulnerabilidad, tales como los prejuicios étnicos, la xenofobia y el racismo, que dificultan la integración de los migrantes a la sociedad y llevan a la impunidad de las violaciones de derechos humanos cometidas en su contra". (Corte IDH, 2003) 
tan los migrantes también se ven enfrentados a algo más grave: una progresiva pérdida de derechos que termina por minar su condición de ciudadanos e incluso su misma humanidad. Una depreciación existencial y axiológica que cosifica y aniquila seres trascendentes y valiosos en sí, por el solo hecho de ser personas. Esta percepción negativa, que ve en los inmigrantes una suerte de "invasores", obedece en parte a la creencia errada de que la pobreza es el principal móvil que anima a un individuo a abandonar su país de origen, sin embargo, como diría la socióloga holandesa Saskia Sassen (2013):

Las migraciones no son, simplemente un flujo indiscriminado de pobreza, como se sugiere en la imaginería de las 'invasiones masivas'. Rindiéndole culto en el altar del perjuicio a la aporofobia como forma de exclusión. Si la pobreza bastara para producir inmigración, entonces los países desarrollados estarían permanentemente amenazados por invasiones masivas. (p.21)

Este tipo de estereotipos ha traído como consecuencia nefasta que los inmigrantes, especialmente quienes se encuentran indocumentados, sean asimilados a ciudadanos de segunda categoría, devaluando su humanidad, al punto tal que, como lo ha expuesto la Corte Interamericana de Derechos Humanos, las violaciones de derechos humanos cometidas en su contra

quedan muchas veces en impunidad debido, inter alia, a la existencia de factores culturales que justifican estos hechos, a la falta de acceso a las estructuras de poder en una sociedad determinada, y a impedimentos normativos y fácticos que tornan ilusorios un efectivo acceso a la justicia. (Corte IDH, 2010)

Como respuesta a los procesos migratorios, los países receptores en aras de preservar su soberanía han adoptado una serie de medidas que en su mayoría son de tipo punitivo, sin que hasta el momento hayan tenido ningún éxito en desestimular el flujo. Por ello, uno de los obstáculos más graves en materia de protección judicial que afecta exclusivamente a los migrantes en situación irregular es que al no ser nacionales del Estado en el que se encuentran y estar en situación irregular suelen tener temor de recurrir a las autoridades para denunciar delitos o violaciones a sus derechos por el miedo de que puedan ser puestas en detención migratoria y eventualmente deportadas. El miedo que es uno de los 4 gigantes del alma, de los que nos habla Emilio Mira y López, que paraliza y mina hasta la vida misma. Esta es una diferencia que es única de los migrantes en situación irregular respecto de otros grupos en situación de vulnerabilidad pero que son nacionales.

No obstante, a la par de la lucha por la soberanía emprendida por los Estados, en los últimos años se ha fortalecido la consciencia sobre la necesidad de proteger la integridad de los inmigrantes, bajo la premisa de que independientemente de su 
estatus migratorio, son sujetos de derechos. Citando nuevamente a Sassen, si bien, no es esta la primera vez que los inmigrantes son percibidos como una amenaza, existen una serie de factores que permiten diferenciar esta etapa de las anteriores:

a. Los estados nacionales se enfrentan a una serie de condiciones económicas que propician la neutralización de las fronteras y modifican la soberanía del Estado y su acción unilateral.

b. El régimen emergente de derechos humanos con pretensiones de universalidad constituye un límite frente a la soberanía estatal que convierte al individuo en un sujeto de derechos independientemente de su nacionalidad.

c. Los cambios constitucionales y judiciales que han experimentado la mayoría de los países del hemisferio occidental, -donde se encuentran la mayoría de los países receptores-, han fortalecido el abanico de derechos de los ciudadanos y de la sociedad civil, incluyendo a los inmigrantes.

Es así como la crisis migratoria que tiene lugar a nivel global y específicamente en América conlleva a una tensión entre la soberanía estatal y la protección de los derechos del individuo, disyuntiva para la cual aún no se avisora una solución tangible en un futuro cercano por las implicaciones económicas, sociales y políticas que entraña. Sin embargo, aunque la Comisión Interamericana de Derechos Humanos ha señalado que los Estados en el ejercicio de su facultad de fijar políticas migratorias tienen derecho a establecer mecanismos de control de ingreso a su territorio y salida de él sobre las personas que no sean nacionales suyas, también ha sido enfática al señalar que dichas políticas deben ser:

Compatibles con las normas de protección de los derechos humanos establecidas en la Convención Americana. Es decir, si bien los Estados guardan un ámbito de discrecionalidad al determinar sus políticas migratorias, los objetivos perseguidos por las mismas deben respetar los derechos humanos de las personas migrantes". (Corte IDH, 2003)

En otros términos, aunque la solución a la crisis migratoria no está a la vuelta de la esquina, tanto los Estados como el Sistema Interamericano de Derechos Humanos tienen en sus manos la posibilidad de atenuar los efectos nocivos que esta problemática tiene en los seres humanos que se ven involucrados en ella, procurando en todo momento preservar su condición de ciudadanos y de sujetos de derechos. Es por esta razón que el ejercicio de toda política migratoria debe tener como faro orientador los siguientes principios y derechos: 
a) Principios de igualdad y no discriminación, b) Principio de interés superior del menor, c) derecho a la libertad personal, d) derecho al tratamiento humano durante la detención, que no debería haberla, e) derecho al debido proceso y acceso a la justicia, f) derecho a la notificación consultar, g) derechos a la vida familiar y a la protección de la unidad familiar, h) derecho a buscar y recibir asilo, i) principio de no devolución y j) prohibición de las expulsiones colectivas.

Especial mención merece el principio de igualdad y no discriminación, en tanto los migrantes pese a que siguen siendo ciudadanos son constante blanco de prejuicios de índole social, cultural, económico e incluso racial, lo que impide que se aplique este principio a cabalidad y se acentúa aún más su situación de vulnerabilidad. Al respecto, la Corte ha señalado:

155. La Corte considera necesario señalar que el deber de respetar y garantizar el principio de igualdad ante la ley y no discriminación es independiente del estatus migratorio de una persona en un Estado. Es decir, los Estados tienen la obligación de garantizar este principio fundamental a sus ciudadanos y a toda persona extranjera que se encuentre en su territorio, sin discriminación alguna por su estancia regular o irregular, su nacionalidad, raza, género o cualquier otra causa. (Corte IDH, 2005) ${ }^{5}$

Lo anterior no quiere decir que los Estados al diseñar su política migratoria no puedan realizar distinciones entre migrantes documentados e indocumentados, 0 entre migrantes y nacionales, "siempre y cuando este trato diferencial sea razonable, objetivo, proporcional y no lesione los derechos humanos" (Corte IDH, 2003).

Ahora bien, aunque todos los principios y derechos que se enumeraron revisten una importancia capital, en este texto nos centraremos en algunos de los señalados: i) el debido proceso como instrumento fundamental en la protección de los derechos de los migrantes; ii) el derecho al acceso a la asistencia consular; iii) la detención de los migrantes, práctica que según la Corte y la Comisión debe ser excepcional, pero que se ha constituido en la regla general de la política migratoria de los Estados; iv) finalmente, se abordarán algunos aspectos relacionados con los derechos y garantías de que gozan los menores de edad en el marco de los controles migratorios.

5 Es importante además señalar que la Corte IDH (2003), en la opinión consultiva sobre la Condición jurídica y derechos de los migrantes indocumentados, señala "113. Existen también prejuicios culturales acerca de los migrantes, que permiten la reproducción de las condiciones de vulnerabilidad, tales como los prejuicios étnicos, la xenofobia y el racismo, que dificultan la integración de los migrantes a la sociedad y llevan la impunidad de las violaciones de derechos humanos cometidas en su contra". 


\section{i. Del debido proceso en el ejercicio de la política y el control migratorio}

Uno de los instrumentos más valiosos con que cuentan los Estados y el Sistema Interamericano de Derechos Humanos - SIDH es el debido proceso, pilar fundamental del Estado de Derecho que constituye un abanico de garantías para el ciudadano que se enfrenta a una actuación desplegada en su contra por el Estado. Si bien, no es posible evitar que los inmigrantes sean sometidos a controles por parte de los Estados receptores, e incluso en algunos casos que sean deportados a su país de origen, sí es posible, y más que una posibilidad es un deber de los Estados miembros propiciar las condiciones para que durante el ejercicio del control los inmigrantes cuenten con todas las garantías que les permitan salvaguardar sus derechos en igualdad de condiciones. El debido proceso es entonces una especie de protección que hace al inmigrante menos vulnerable, en una situación en la que debe enfrentarse a un proceso judicial o administrativo en un país desconocido.

No está demás decir que este principio debe aplicarse independientemente de la situación jurídica del migrante, como lo ha señalado la Corte Interamericana de Derechos Humanos al pronunciarse sobre el Caso Loor vs. Panamá:

143. El debido proceso legal es un derecho que debe ser garantizado a toda persona, independientemente de su estatus migratorio. Esto implica que el Estado debe garantizar que toda persona extranjera, aún cuando fuere un migrante en situación irregular tenga la posibilidad de hacer valer sus derechos y defender sus intereses en forma efectiva y en condiciones de igualdad procesal con otros justiciables. (Corte IDH, 2010) ${ }^{6}$

De igual forma, la obligación de observar las garantías del debido proceso rige en todo tipo de procedimientos de control migratorio, es decir, sin importar si son de naturaleza judicial o administrativa, por lo que todas las autoridades del Estado están obligadas a respetar las garantías propias de este principio como se desprende del artículo 8o de la Convención Americana sobre Derechos Humanos y también lo ha señalado la Corte en varias ocasiones ${ }^{7}$. Podríamos afirmar incluso, que

6 La Corte ya se había pronunciado en términos similares en la opinión consultiva sobre la Condición Jurídica de los inmigrantes indocumentados: "La Corte considera que el derecho al debido proceso legal debe ser reconocido en el marco de las garantías mínimas que se deben brindar a todo migrante, independientemente de su estatus migratorio. El amplio alcance de la intangibilidad del debido proceso se aplica no solo ratione materiae sino también ratione personae sin discriminación alguna". (CIDH, 2003)

7 "Es por ello que se exige que cualquier autoridad pública, sea administrativa, legislativa o judicial, cuyas decisiones puedan afectar los derechos de las personas, adopte tales decisiones con pleno respeto de las garantías del debido proceso legal. Así, el artículo 8 de la Convención consagra los lineamientos del debido proceso legal, el cual está compuesto de un conjunto de requisitos que deben observarse en las instancias procesales, a efectos de que las personas estén en condiciones de defender adecuadamente sus derechos ante cualquier tipo de acto del Estado que pueda afectarlos. Adicionalmente, la Corte ha interpretado que el elenco de garantías mínimas establecido en el numeral 
desde la óptica del debido proceso los migrantes son sujetos de especial protección convencional comoquiera que frente a ellos la observancia de este principio debe ser incluso más rigurosa, en razón a sus condiciones particulares, en las que deben enfrentar un proceso en un país y una cultura desconocida, y en muchas ocasiones están inmersos en una serie de prejuicios que minan el derecho al trato igualitario.

Ahora bien, podría decirse que son dos los principios que constituyen la columna vertebral del debido proceso:

\section{El Derecho a la imparcialidad e independencia del juez of funcionario que} adelanta el procedimiento. El Estado debe garantizar que la autoridad administrativa o judicial que adelanta el procedimiento migratorio sea completamente imparcial e independiente, a fin de procurar en todo momento un trato igualitario. Es pertinente recordar, que como lo ha señalado la Corte Interamericana de Derechos Humanos, la jurisdicción militar no puede ser el fuero competente en materia de derechos humanos, y por ende tampoco puede serlo en asuntos migratorios, toda vez que no ofrece las garantías de imparcialidad e independencia exigidas en la Convención Americana sobre Derechos Humanos, y tampoco permiten interponer recursos efectivos contra sus decisiones. (Corte IDH, 2012)

2. El derecho de defensa, que obliga al Estado "a tratar al individuo en todo momento como un verdadero sujeto del proceso, en el más amplio sentido de este concepto, y no simplemente como objeto del mismo" (Corte IDH, 2010). En este orden de ideas, el Estado tiene la obligación de proveer asistencia jurídica gratuita al ciudadano que se enfrenta a un procedimiento cuyo desenlace podría ser la deportación, expulsión o la privación de la libertad, lo contrario podría entrañar una violación al debido proceso, como se declaró en la sentencia sobre el caso Loor vs. Panamá y en la que se resaltó la importancia de la asistencia letrada, que sea una asistencia técnica y no meramente formal; letrados competentes y comprometidos con los derechos humanos y los derechos de los migrantes:

132. En este contexto, es de resaltar la importancia de la asistencia letrada en casos como el presente, en que se trata de una persona extranjera, que puede no conocer el sistema legal del país y que se encuentra en una situación agravada de vulnerabilidad al encontrarse privada de la libertad, lo cual requiere que el Estado receptor tome en cuenta las particularidades de su situación, para que goce de un acceso efectivo a la justicia en términos igualitarios. Así, el Tribunal estima que la asistencia debe ser ejercida por un profesional del Derecho para poder satisfacer los requisitos de una defensa técnica a través

2 del artículo 8 de la Convención se aplica también a la determinación de derechos y obligaciones de orden 'civil, laboral, fiscal o de cualquier otro carácter'. Por esta razón, no puede la administración dictar actos administrativos sancionatorios sin otorgar también a las personas sometidas a dichos procesos las referidas garantías mínimas, las cuales se aplican mutatis mutandis en lo que corresponda". (CIDH, 2010) 
de la cual se asesore a la persona sometida a proceso, inter alia, sobre la posibilidad de ejercer recursos contra actos que afecten derechos. Si el derecho a la defensa surge desde el momento en que se ordena investigar a una persona o la autoridad dispone o ejecuta actos que implican afectación de derechos, la persona sometida a un proceso administrativo sancionatorio debe tener acceso a la defensa técnica desde ese mismo momento. Impedir a éste contar con la asistencia de su abogado defensor es limitar severamente el derecho a la defensa, lo que ocasiona desequilibrio procesal y deja al individuo sin tutela frente al ejercicio del poder punitivo. ${ }^{8}$ (Corte IDH, 2010)

\section{ii. Derecho al acceso a la asistencia consular}

El Derecho al acceso a la asistencia consular se encuentra consagrado en el artículo 36 de la Convención de Viena sobre Relaciones Consulares ${ }^{9}$ y constituye un derecho individual y una garantía mínima que busca remediar la situación del ciudadano que se encuentra en unas condiciones particularmente vulnerables, con el fin de garantizar que pueda ejercer su derecho de defensa en igualdad de condiciones. Es así, como la asistencia consular consta de tres componentes fundamentales para la persona que se enfrenta a un procedimiento migratorio: 1) el derecho a ser notificado de sus derechos bajo la Convención de Viena, 2) el

8 "La Corte ha considerado que, en procedimientos administrativos o judiciales en los cuales se pueda adoptar una decisión que implique la deportación, expulsión o privación de libertad, la prestación de un servicio público gratuito de defensa legal a favor de éstas es necesaria para evitar la vulneración del derecho a las garantías del debido proceso. En efecto, en casos como el presente en que la consecuencia del procedimiento migratorio podría ser una privación de la libertad de carácter punitivo, la asistencia jurídica gratuita se vuelve un imperativo en interés de la justicia" (CIDH, 2010).

9 “Artículo 36. COMUNICACIÓN CON LOS NACIONALES DEL ESTADO QUE ENVIA

1. Con el fin de facilitar el ejercicio de las funciones consulares relacionadas con los nacionales del Estado que envía:

a) los funcionarios consulares podrán comunicarse libremente con los nacionales del Estado que envía y visitarlos. Los nacionales del Estado que envía deberán tener la misma libertad de comunicarse con los funcionarios consulares de ese Estado y de visitarlos;

b) si el interesado lo solicita, las autoridades competentes del Estado receptor deberán informar sin retraso alguno a la oficina consular competente en ese Estado cuando, en su circunscripción, un nacional del Estado que envía sea arrestado de cualquier forma, detenido o puesto en prisión preventiva. Cualquier comunicación dirigida a la oficina consular por la persona arrestada, detenida o puesta en prisión preventiva, le será asimismo transmitida sin demora por dichas autoridades, las cuales habrán de informar sin dilación a la persona interesada acerca de los derechos que se le reconocen en este apartado;

c) los funcionarios consulares tendrán derecho a visitar al nacional del Estado que envía que se halle arrestado, detenido o en prisión preventiva, a conversar con él y a organizar su defensa ante los tribunales. Asimismo, tendrán derecho a visitar a todo nacional del Estado que envía que, en su circunscripción, se halle arrestado, detenido o preso en cumplimiento de una sentencia. Sin embargo, los funcionarios consulares se abstendrán de intervenir en favor del nacional detenido, cuando éste se oponga expresamente a ello.

2. Las prerrogativas a las que se refiere el párrafo 1 de este artículo se ejercerán con arreglo a las leyes y reglamentos del Estado receptor, debiendo entenderse, sin embargo, que dichas leyes y reglamentos no impedirán que tengan pleno efecto los derechos reconocidos por este artículo". (ONU, 1963) 
derecho al acceso efectivo a la comunicación con el funcionario consular, y 3) el derecho a la asistencia misma.

De acuerdo con lo anterior, puede concluirse que entre muchos otros ejemplos, podría decirse que se vulneran las garantías del debido proceso en los siguientes casos:

a. Cuando una persona acude a las instancias administrativas o judiciales y corre el riesgo de ser deportada, expulsada o privada de la libertad.

b. Cuando se deniega la prestación del servicio público gratuito de defensa legal.

Ahora bien, en relación a las expulsiones o deportaciones, la Corte ha sido vehemente al señalar que las mismas no pueden realizarse de manera masiva, sino que el Estado está obligado a estudiar cada caso individualmente, de modo que pueda evaluar las circunstancias personales de cada migrante sin que le esté permitido otorgar algún trato discriminatorio en razón de la raza, el género, la religión, o la condición social o económica del sujeto. Además, en el proceso de evaluación sobre la procedencia de expulsión el sujeto tiene derecho a que se le respeten como mínimo las siguientes garantías (Corte IDH, 2012):

i. Ser informado expresa y formalmente de los cargos formulados en su contra si los hubiere, y los motivos de la expulsión o deportación. En esta notificación debe informársele de la posibilidad que tiene de exponer las razones que considere lo asisten para no ser expulsado y a oponerse a los cargos en su contra. De igual forma, debe brindársele información sobre la posibilidad de solicitar y recibir asesoría legal, e incluso gratuita, y la posibilidad de recibir asistencia consular.

ii. En el evento de decisión desfavorable, debe tener derecho de someter el caso a revisión ante la autoridad competente.

iii. La eventual expulsión sólo podrá decretarse tras una decisión fundamentada en la ley y que sea debidamente notificada.

Como puede apreciarse, la Corte se ha opuesto enfáticamente a las expulsiones de facto, en las que no existe la más mínima posibilidad de analizar las circunstancias en que se encuentra cada individuo y éste no tiene la posibilidad de ejercer su derecho de defensa. En pocos términos, la expulsión o deportación solo procede una vez se haya agotado el trámite previsto para tal efecto y siempre y cuando se le hayan brindado al sujeto todas las garantías inherentes al debido proceso, por lo que están vedadas las expulsiones colectivas que se realizan de manera arbitraria y obedecen a la pura y simple voluntad de la autoridad que las lleva a cabo (Corte IDH, 2012). Esto, por cuanto se reitera, aunque los Estados están en todo el derecho de diseñar y ejecutar una política migratoria que les permita ejercer y 
conservar la soberanía sobre su territorio, también están obligados a respetar los derechos consagrados en la Convención Americana sobre Derechos Humanos, sin importar el estatus migratorio del individuo. Con todo, es importante aclarar que el carácter colectivo de la expulsión no se determina por el número de personas expulsadas sino porque la decisión no se basó en la ponderación objetiva de las circunstancias individuales de cada extranjero (Corte IDH, 2014), es decir, que el Estado puede tomar la determinación de expulsar a un número considerable de migrantes, sin violar los derechos de la Convención, siempre y cuando haya evaluado cada caso particular de manera individualizada y su decisión no haya obedecido a prejuicios o motivos discriminatorios.

Además, la misma Convención en su artículo 22.8 prohíbe la expulsión o devolución de cualquier extranjero a otro país, sea o no de origen, cuando su derecho a la vida o a la libertad estén en "riesgo de violación a causa de raza, nacionalidad, religión, condición social o de sus opiniones políticas", aspecto que actualmente reviste una especial relevancia por la situación que atraviesan los países del Triángulo Norte, de los cuales cientos de personas se ven obligadas a huir con motivo de la situación de violencia generalizada que azota a la región. Es importante resaltar que la prohibición de devolución no aplica solo en relación a los asilados o refugiados, sino frente a toda persona cuya vida o libertad personal se encuentre en riesgo por las situaciones mencionadas. Así lo expresó la Corte en el caso Pacheco Tineo vs. Bolivia:

135. De tal modo, si se complementan las normas anteriores con el corpus juris internacional aplicable a las personas migrantes, es posible considerar que en el sistema interamericano está reconocido el derecho de cualquier persona extranjera, y no solamente a los asilados o refugiados, a la no devolución indebida cuando su vida, integridad y/o libertad estén en riesgo de violación, sin importar su estatuto legal o condición migratoria en el país en que se encuentre.

136. En consecuencia, cuando un extranjero alegue ante un Estado un riesgo en caso de devolución, las autoridades competentes de ese Estado deberán, al menos, entrevistar a la persona y realizar una evaluación previa o preliminar, a efectos de determinar si existe o no ese riesgo en caso de expulsión. Esto implica respetar las garantías mínimas referidas, como parte de la debida oportunidad de exponer las razones que lo asisten en contra de su expulsión y, si se constata ese riesgo, no debería ser devuelto a su país de origen o donde exista el riesgo. (Corte IDH, 2012)

De igual forma, el artículo 13 del Pacto Internacional de Derechos Civiles y Políticos señala: 
El extranjero que se halle legalmente en el territorio de un Estado Parte en el presente Pacto sólo podrá ser expulsado de él en cumplimiento de una decisión adoptada conforme a la ley; y, a menos que razones imperiosas de seguridad nacional se opongan a ello, se permitirá a tal extranjero exponer las razones que lo asistan en contra de su expulsión, así como someter su caso a revisión ante la autoridad competente o bien ante la persona o personas designadas especialmente por dicha autoridad competente, y hacerse representar con tal fin ante ellas. (ONU, 1966)

Otros instrumentos en los que se ha consagrado la prohibición de expulsiones colectivas son la Declaración Universal de los Derechos Humanos (artículos 9, 13.1 y 13.29), el Protocolo del Convenio Europeo de Derechos Humanos (artículo 4); y el Pacto Internacional sobre la Eliminación de todas las Formas de Discriminación Racial (art. 5우).

No cabe duda entonces, de que hoy en día la práctica de las expulsiones colectivas está vedada en el sistema interamericano y en el Tribunal Europeo de Derechos Humanos - TEDH, no solo porque pone en riesgo el derecho de residencia y tránsito, sino también otros derechos como la vida, la libertad y la seguridad de la persona, el derecho a buscar y recibir asilo, el principio de no devolución, el derecho al debido proceso, a la protección de la unidad familiar, a la vida privada y los derechos del niño. Se itera, al Estado no le está prohibido expulsar a un extranjero de su territorio, lo que le está vedado es que lo haga sin respetar las garantías mínimas del debido proceso y sin sopesar y analizar individualmente las circunstancias de cada caso particular.

\section{iii. La privación de la libertad como carácter excepcional: la migración no es un delito}

Los estereotipos contra los migrantes, quienes son vistos como "invasores", han conducido a la nociva práctica de centrar las políticas migratorias en el derecho penal, criminalizando el hecho de ingresar o permanecer en un país de manera ilegal. Esta práctica, lejos de desestimular el flujo migratorio lo único que ha logrado es que los migrantes sean asimilados a delincuentes, lo que ha elevado las conductas de xenofobia y discriminación hacia ellos, y a su vez ha acentuado sus condiciones de vulnerabilidad ${ }^{10}$. De igual forma, la criminalización de la migración

10 "Junto a la afirmación de que la migración representa una amenaza para la seguridad nacional, los Estados Unidos han buscado justificar su ahora [sic] el actual uso automático del régimen de detención de familias migrantes a su llegada al país y/o su aprehensión, como medidas de disuasión contra la migración irregular. La práctica de la detención migratoria también sirve para criminalizar la migración, lo cual tiene múltiples efectos negativos sobre la 
ha hecho de las medidas de detención la regla general, cuando en realidad debería ser la excepción.

La libertad es un principio, un valor y un Derecho y la detención es la última ratio para restringirla, los Estados no pueden seguir actuando como aquel falso ídolo del que habla Zaratustra, que en un plano formal garantiza un Derecho y en el otro lo desconoce, la migración no se puede criminalizar.

Ahora bien, la imposición de medidas que afecten la libertad personal, debe darse en el marco de las garantías previstas en el artículo 7ํ de la Convención ${ }^{11}$, es decir, que la detención debe estar debidamente fundamentada y no procede de manera automática por el solo hecho de encontrarse inmerso en una situación migratoria irregular. En otros términos, la migración, sea regular o irregular no es un delito, posición que ha sido compartida por el Relator Especial sobre los Derechos Humanos de los Migrantes de Naciones Unidas al afirmar que "la entrada o permanencia irregular nunca debieran ser considerados delitos penales: no constituyen per se delitos contra las persona, los bienes o la seguridad nacional". (CIDH, 2015).

De igual forma, en caso de que se imponga la detención el sujeto tiene el derecho de recurrir la decisión ante una autoridad judicial, de conformidad con el artículo 7.6 de la Convención, que establece expresamente que la autoridad que debe pronunciarse sobre la detención debe ser "un juez o tribunal", de manera que cuando el encargado de resolver el recurso sea una autoridad administrativa se estará vulnerando el derecho al debido proceso y las garantías judiciales del

protección de los derechos de los migrantes y la percepción social de los migrantes, y puede fomentar la xenofobia en su contra". (CIDH, 2015)

11 "Artículo 7. Derecho a la Libertad Personal.

1. Toda persona tiene derecho a la libertad y a la seguridad personales.

2. Nadie puede ser privado de su libertad física, salvo por las causas y en las condiciones fijadas de antemano por las Constituciones Políticas de los Estados Partes o por las leyes dictadas conforme a ellas.

3. Nadie puede ser sometido a detención o encarcelamiento arbitrarios.

4. Toda persona detenida o retenida debe ser informada de las razones de su detención y notificada, sin demora, del cargo o cargos formulados contra ella.

5. Toda persona detenida o retenida debe ser llevada, sin demora, ante un juez u otro funcionario autorizado por la ley para ejercer funciones judiciales y tendrá derecho a ser juzgada dentro de un plazo razonable o a ser puesta en libertad, sin perjuicio de que continúe el proceso. Su libertad podrá estar condicionada a garantías que aseguren su comparecencia en el juicio.

6. Toda persona privada de libertad tiene derecho a recurrir ante un juez o tribunal competente, a fin de que éste decida, sin demora, sobre la legalidad de su arresto o detención y ordene su libertad si el arresto o la detención fueran ilegales. En los Estados Partes cuyas leyes prevén que toda persona que se viera amenazada de ser privada de su libertad tiene derecho a recurrir a un juez o tribunal competente a fin de que éste decida sobre la legalidad de tal amenaza, dicho recurso no puede ser restringido ni abolido. Los recursos podrán interponerse por sí o por otra persona.

7. Nadie será detenido por deudas. Este principio no limita los mandatos de autoridad judicial competente dictados por incumplimientos de deberes alimentarios.". (OEA, 1969) 
ciudadano. En este orden de ideas, de conformidad con la jurisprudencia de la Corte, toda medida de privación de la libertad, independientemente de su legalidad, debe reunir los siguientes requisitos:

a. Que la finalidad de las medidas que priven o restrinjan la libertad sea compatible con la Convención Americana sobre Derechos Humanos.

b. Que las medidas adoptadas sean las idóneas para cumplir con el fin perseguido.

Sobre estos dos requisitos, la Corte ha señalado que el fin de controlar y regular el ingreso y permanencia de extranjeros a su territorio puede ser un fin legítimo, por lo que las detenciones preventivas pueden ser una medida idónea para regular y controlar la migración irregular, para asegurar la comparecencia de la persona al proceso migratorio o para garantizar la ejecución de una orden de deportación. Sin embargo, según el Grupo de Trabajo sobre la Detención Arbitraria, "la penalización de la entrada irregular en un país supera el interés legítimo de los Estados en controlar y regular la inmigración irregular y puede dar lugar a detenciones innecesarias" (ONU, 2008). En el mismo sentido se ha pronunciado la Corte Interamericana de Derechos Humanos, al señalar que la "finalidad de imponer una medida punitiva al migrante que reingresara de manera irregular al país tras una orden de deportación previa no constituye una finalidad legítima de acuerdo a la Convención" (Corte IDH, 2010).

c. Que sean necesarias, es decir, absolutamente indispensables para conseguir el fin deseado, siempre y cuando no exista una medida menos gravosa respecto del derecho intervenido. La detención de personas por incumplimiento de leyes migratorias nunca debe ser con fines punitivos.

d. Que sean estrictamente proporcionales, de modo que el sacrificio inherente a la restricción del derecho a la libertad no resulte exagerado o desmedido frente a las ventajas que se obtienen mediante esa restricción y el cumplimiento de la finalidad perseguida.

En este orden de ideas, no basta con que la detención sea legal, sino que además no debe ser arbitraria, como lo ha señalado la Corte, cualquier detención no solo debe ajustarse a la disposiciones de derecho interno, sino que además es necesario que la ley del Estado sea compatible con la Convención Americana sobre Derechos Humanos, en otros términos, "no se debe equiparar el concepto de 'arbitrariedad' con el de 'contrario a la ley', sino que debe interpretarse de manera más amplia a fin de incluir elementos de incorrección, injusticia e imprevisibilidad"12 (Corte IDH, 2012). De igual forma, del mismo modo que las expulsiones colectivas se encuentran prohibidas, la Corte también ha manifestado su oposición a las detenciones programadas colectivas toda vez que no están fundadas en la individualización 
de las conductas punibles y carecen de control judicial y, por ende, vulneran el derecho a la presunción de inocencia y "transforman la detención preventiva en un mecanismo discriminatorio, por lo que el Estado no puede realizarlas, en circunstancia alguna" (Corte IDH, 2014).

En todo caso, aún cuando se reúnan estos requisitos, la detención también debe reunir unas condiciones especiales, toda vez que las personas detenidas en razón de su situación migratoria deben permanecer en lugares distintos a los destinados a las personas acusadas o condenadas por la comisión de delitos penales. En palabras de la Corte:

Cuando se trata de migrantes, la detención y privación de la libertad por su sola situación migratoria irregular, debe ser utilizada cuando fuere necesario y proporcionado en el caso concreto, solamente admisible durante el menor tiempo posible y en atención a los fines legítimos referidos. (Corte IDH, 2010)

Además, las medidas restrictivas de la libertad deben evitar en lo posible la desintegración de los núcleos familiares.

\section{iv. Particularidades del debido proceso frente a los menores de edad}

Quisiera hacer una breve alusión a las particularidades que reviste el debido proceso en materia migratoria cuando se encuentran involucrados menores de edad, quienes son sujetos de una mayor protección ${ }^{13}$. Con el fin de verificar si el menor que ingresa a un Estado está en riesgo, el Estado debe realizar una evaluación sobre las condiciones que llevaron al menor a abandonar su país de origen

"82. Por consiguiente, a raíz del abanico de situaciones que pueden llevar a que una niña o un niño se desplace de su país de origen (...) resulta relevante diferenciar entre aquellos que migran en búsqueda de oportunidades para mejorar su nivel de vida, de quienes requieren algún tipo de protección internacional, incluyendo pero no limitada la protección de refugiados y solicitantes de asilo (...). Es por ello

13 En palabras de la Corte Interamericana de Derechos Humanos: "115. En definitiva, tal y como lo ha sostenido anteriormente esta Corte, si bien el debido proceso y sus correlativas garantías son aplicables a todas las personas, en el caso de las niñas y niños migrantes, el ejercicio de aquellos supone, por las condiciones especiales en las que se encuentran, la adopción de ciertas medidas específicas con el propósito de asegurar un acceso a la justicia en condiciones de igualdad, garantizar un efectivo debido proceso y velar porque el interés superior se erija en una consideración primordial en todas las decisiones administrativas o judiciales que se adopten. Sobre estas consideraciones se deben formular los procesos administrativos o judiciales en los que se resuelva acerca de derechos de las niñas o niños migrantes y, en su caso, de las personas bajo cuya potestad o tutela se hallan aquéllos, los cuales deben ajustarse a su condición, necesidades y derechos". Corte IDH. (2014a). 
que, para cumplir con los compromisos internacionales, los Estados se encuentran obligados a identificar a las niñas y niños extranjeros que requieren de protección internacional dentro de sus jurisdicciones, ya sea como refugiado o de algún otro tipo, a través de una evaluación inicial con garantías de seguridad y privacidad, con el fin de proporcionales el tratamiento adecuado e individualizado que sea necesariamente mediante la adopción de medidas de protección especial. La Corte considera que el establecimiento de procedimientos de identificación de necesidades de protección es una obligación positiva de los Estados y no instituirlos constituiría una falta de debida diligencia. (Corte IDH, 2014a)

Este procedimiento de evaluación debe tener en cuenta los siguientes componentes, además de las garantías propias del debido proceso:

a. Tratamiento acorde a su condición de niño o niña, y en caso de duda sobre la edad, evaluación y determinación de la misma.

b. Determinación de si se trata de una niña o un niño no acompañado o separado. En este caso, el Estado debe respetar unas garantías específicas, comoquiera que los menores que no se encuentran acompañados o separados de su familia, son vulnerables a situaciones de trata infantil, explotación y malos tratos.

c. Determinación de la nacionalidad de la niña o del niño, o en su caso, de su condición de apátrida.

d. Adopción, en caso de ser necesario y pertinente de acuerdo con el interés superior del menor, de medidas de protección especial.

e. Derecho a ser notificado de la existencia de un procedimiento y de la decisión que se adopte en el marco del proceso migratorio.

f. Derecho a que los procesos migratorios sean llevados por un funcionario o juez especializado.

g. Derecho de la niña o niño a ser oído y a participar en las diferentes etapas procesales.

h. Derecho a ser asistido gratuitamente por un traductor o intérprete.

i. Acceso efectivo a la comunicación y asistencia consular.

j. Derecho a ser asistido por un representante legal y a comunicarse libremente con dicho representante.

k. Deber de designar un tutor en caso de niñas o niños no acompañados o separados. 
1. Derecho a que la decisión que se adopte evalúe el interés superior de la niña o del niño y sea debidamente fundamentada.

m. Derecho a recurrir la decisión ante un juez o tribunal superior con efectos suspensivos.

n. Plazo razonable de duración del proceso.

Ahora bien, si por regla general la detención de una persona por su situación migratoria debe ser excepcional, cuando hay menores involucrados la privación de la libertad no debe aplicarse ni siquiera como ultima ratio. Así lo ha expresado la Corte:

154. Entonces, la medida de privación de la libertad, si bien puede perseguir una finalidad legítima y resultar idónea para alcanzarla, al conjugar los criterios desarrollados y en virtud del principio de interés superior de la niña o del niño, la Corte es de la opinión que la privación de la libertad de niñas o de niños por razones exclusivas de índole migratoria excede el requisito de necesidad, toda vez que tal medida no resulta absolutamente indispensable a los fines de asegurar su comparecencia al proceso migratorio o para garantizar la aplicación de una orden de deportación (...) Aunado a ello, la Corte es de la opinión que la privación de la libertad de una niña o niño en este contexto de ninguna manera podría ser entendida como una medida que responda a su interés superior. En este sentido, la Corte considera que existen medidas menos gravosas (...) que podrían ser idóneas para alcanzar tal fin y, al mismo tiempo, responder al interés superior de la niña o del niño. En suma, la Corte es de la opinión que la privación de la libertad de un niño o niña migrante en situación irregular, decretada por esta única circunstancia, es arbitraria y por ende, contraria tanto a la Convención como a la Declaración Americana. (Corte IDH, 2014a)

No cabe duda entonces, de que la privación de la libertad no es una opción cuando se trata de un menor de edad, sobre todo si ese menor de edad no se encuentra acompañado o está separado de su familia. Ahora bien, en el caso contrario, es decir, si el menor está acompañado de su familiar, en razón del interés superior del niño debe procurarse el mantenimiento de la unidad familiar, por lo que el imperativo de no privación de la libertad se extiende a sus padres y obliga a las autoridades a adoptar otras medidas para la detención de la familia, como centros de acogida destinados únicamente a ese fin, en donde se reúnan las condiciones adecuadas para el bienestar y la protección del menor. En otros términos, tratándose de migrantes menores de edad, el principio de separación adquiere dos dimensiones: 1) si se trata de niñas o niños no acompañados o separados, deben alojarse en sitios distintos al que corresponde a los adultos y 2) si se trata 
de menores acompañados, deben alojarse con sus familiares, salvo que lo más conveniente sea la separación en aplicación del principio del interés superior de la niña o del niño ${ }^{14}$ (Corte IDH, 2014a).

Ahora bien, lo anterior no obsta para que en ciertos casos el menor pueda ser separado de uno de sus progenitores como consecuencia de la deportación de uno o ambos padres, tal como señala el artículo 9o de la Convención Sobre los Derechos del Niño ${ }^{15}$.

\section{Conclusiones del debido proceso y derechos de los migrantes}

Lo dicho hasta el momento deja claro que en el sistema interamericano existen un abanico de garantías para proteger los derechos de los migrantes, sin embargo, los prejuicios y la percepción errada que se tiene de los migrantes ha impedido que estas garantías se apliquen íntegramente y además, en la mayoría de los casos, cuando los migrantes son víctimas de violaciones a sus derechos estas situaciones quedan en la impunidad. ¿Pueden imaginarse cómo es la situación para las personas migrantes cuando requieren protección judicial? ¿Pueden imaginarse qué sucede con la mayoría de delitos y violaciones a derechos humanos de las que son víctimas los migrantes en lugares aislados o de difícil acceso tales como zonas fronterizas, rutas migratorias, zonas internaciones de aeropuertos en altamar o centros de detención migratoria?

Las fronteras y muchos de los lugares por los que los migrantes se ven forzados a desplazarse se han convertido en lugares de quiebre para la justicia y los

14 La Corte IDH (2014a) también ha señalado que "la definición de familia no debe restringirse por la noción tradicional de una pareja y sus hijos, pues también pueden ser titulares del derecho a la vida familiar otros parientes, como los tíos, primos y abuelos, para enumerar solo algunos miembros posibles de la familia extensa, siempre que tengan lazos cercanos personales. Además, en muchas familias la(s) persona(s) a cargo de la atención, el cuidado y el desarrollo de una niña o niño en forma legal o habitual no son los padres biológicos. Más aún, en el contexto migratorio, los "lazos familiares" pueden haberse constituido entre personas que no necesariamente sean jurídicamente parientes, máxime cuando, en lo que respecta a niñas y niños, no han contado con sus padres en tales procesos".

15 Artículo 9. Los Estados Partes velarán por que el niño no sea separado de sus padres contra la voluntad de éstos, excepto cuando, a reserva de revisión judicial, las autoridades competentes determinen, de conformidad con la ley y los procedimientos aplicables, que tal separación es necesaria en el interés superior del niño. Tal determinación puede ser necesaria en casos particulares, por ejemplo, en los casos en que el niño sea objeto de maltrato o descuido por parte de sus padres o cuando éstos viven separados y debe adoptarse una decisión acerca del lugar de residencia del niño.

(...)

4. Cuando esa separación sea resultado de una medida adoptada por un Estado Parte, como la detención, el encarcelamiento, el exilio, la deportación o la muerte (incluido el fallecimiento debido a cualquier causa mientras la persona esté bajo la custodia del Estado) de uno de los padres del niño, o de ambos, o del niño, el Estado Parte proporcionará, cuando se le pida, a los padres, al niño o, si procede, a otro familiar, información básica acerca del paradero del familiar o familiares ausentes, a no ser que ello resultase perjudicial para el bienestar del niño. Los Estados Partes se cerciorarán, además, de que la presentación de tal petición no entrañe por sí misma consecuencias desfavorables para la persona o personas interesadas. 
derechos humanos. Las dificultades para acceder a estos lugares hacen que en muchos casos no haya abogados u organizaciones que puedan brindar asistencia legal a estas personas. Aunado a esto, muchas de las violaciones a los derechos humanos de los migrantes se realizan de forma sumaria, tales como rechazos en frontera, deportaciones expeditas o "en caliente", entre otras.

No está de más mencionar que el acceso a la justicia es un derecho humano fundamental en un sistema democrático que tenga por objeto garantizar los derechos de todos por igual. Cuando otros derechos son violados, constituye la vía para reclamar su cumplimiento ante los tribunales y garantizar la igualdad ante la ley. En palabras de Boaventura de Sousa Santos (1998):

Por un lado, la consagración constitucional de los nuevos derechos económicos y sociales y su nueva expansión paralela a la del EstadoProvidencia, transformó el derecho del acceso efectivo a la justicia en un derecho bisagra, un derecho cuya denegación acarrearía la de todos los demás. Una vez despojados de mecanismos que hicieran imponer su respeto, los nuevos derechos sociales y económicos pasarían a ser meras declaraciones políticas, con contenido y función mistificadores. (p. 201)

La forma en que los Estados se comprometen con la realización del acceso a la justicia denota su nivel de compromiso en crear condiciones para que la igualdad y la libertad de todas las personas sean efectivas y reales. Sin la posibilidad de hacer exigibles los derechos, éstos no son más que cláusulas vacías de contenido.

Igualmente quisiera llamar la atención sobre uno de los principales aportes de la jurisprudencia de los órganos del Sistema Interamericano de Derechos Humanos a nivel mundial: la reparación integral de las víctimas, que también cobija a los migrantes cuyos derechos se han visto vulnerados. El derecho a la protección judicial necesariamente comprende la reparación integral de las víctimas a través de la adopción de medidas de reparación tales como la restitución -la llamada restitutio in integrum-, medida que siempre debe intentarse en primer lugar; la indemnización; la rehabilitación; la satisfacción; y las garantías de no repetición. En este sentido se han observado ejemplos bastante interesantes por parte de las cortes nacionales que cada vez con mayor frecuencia integran este concepto de reparación integral y ordenan diversas medidas en materia de reparación.

Ahora bien, la reciente sentencia del Tribunal Europeo de Derechos Humanos - TEDH (2017), sobre la expulsión sumaria de dos personas llevada a cabo el 13 de agosto de 2014 en Melilla, condenó al Reino de España en este punto a una reparación pecuniaria de daño moral en favor de cada uno de los demandantes.

Quisiera concluir este acápite con una pregunta, ¿hasta qué punto consideramos que se están garantizando los derechos a la protección judicial y al debido 
proceso respecto de las personas migrantes y sujetas de protección internacional? Ésta cobra relevancia en este momento en el que no solo existe una ola de violencia en varios países centroamericanos, que ha obligado a cientos de sus habitantes a emigrar, sino que también en los próximos años el cambio climático representará grandes desafíos para los Estados en el diseño y ejercicio de sus políticas migratorias. En todo caso, lo cierto es que independientemente de las razones que motivan a una persona a salir de su país de origen, no puede perderse de vista que un ser humano puede ser despojado de su lugar de arraigo, pero nunca de su condición de ciudadano y menos de la de ser humano.

\section{Asilo de calidad: estándares internacionales del procedimiento de determinación de la condición de refugiado}

Las migraciones masivas que se vienen presentando en los últimos años no solo han dado lugar a que se acentúen los sentimientos de xenofobia y estigmatización del extranjero, sino que además han debilitado los derechos de los refugiados, quienes con frecuencia son confundidos con los inmigrantes. Por eso, antes de hacer referencia a los criterios para determinar quién tiene la condición de refugiado es indispensable aprender a diferenciar ambas categorías: mientras los emigrantes se caracterizan porque deciden dejar su país de origen por voluntad propia, bien sea por razones laborales o porque van simplemente en busca de aventuras o de un mejor nivel de vida, la característica principal de los refugiados es que:

(...) buscan protección en otro país, no por elección sino por una necesidad imperiosa, a fin de escapar a las amenazas de sus derechos humanos más fundamentales y de las que las autoridades de su país de origen o de residencia habitual no pueden o no quieren protegerlos. (ACNUR, 2006)

En este orden de ideas, es preciso tener en cuenta que cuando estamos ante un refugiado, estamos en presencia de alguien que se ha visto obligado a dejar su país porque la permanencia en él implica un verdadero riesgo para su vida o su integridad física.

Pese a que la cuestión de los refugiados ha cobrado relevancia a nivel mundial con las migraciones masivas que se han presentado en los últimos años, es preciso advertir que no se trata de un problema reciente. De hecho, el derecho internacional de los refugiados encuentra su principal fundamento jurídico en la Convención sobre el Estatuto de los Refugiados de 1951 -en adelante también la Convención-, que constituye la carta de navegación para determinar si alguien ostenta esa calidad. El artículo $1^{\mathfrak{o}}$ de este instrumento señala:

Artículo 1. -- Definición del término "refugiado" 
A los efectos de la presente Convención, el término "refugiado" se aplicará a toda persona:

1) Que haya sido considerada como refugiada en virtud de los Arreglos del 12 de mayo de 1926 y del 30 de junio de 1928, o de las Convenciones del 28 de octubre de 1933 y del 10 de febrero de 1938, del Protocolo del 14 de septiembre de 1939 o de la Constitución de la Organización Internacional de Refugiados.

Las decisiones denegatorias adoptadas por la Organización Internacional de Refugiados durante el período de sus actividades, no impedirán que se reconozca la condición de refugiado a personas que reúnan las condiciones establecidas en el párrafo 2 de la presente sección.

2) Que, como resultado de acontecimientos ocurridos antes del 1.응 de enero de 1951 y debido a fundados temores de ser perseguida por motivos de raza, religión, nacionalidad, pertenencia a determinado grupo social u opiniones políticas, se encuentre fuera del país de su nacionalidad y no pueda o, a causa de dichos temores, no quiera acogerse a la protección de tal país; o que, careciendo de nacionalidad y hallándose, a consecuencia de tales acontecimientos, fuera del país donde antes tuviera su residencia habitual, no pueda o, a causa de dichos temores, no quiera regresar a él. En los casos de personas que tengan más de una nacionalidad, se entenderá que la expresión "del país de su nacionalidad" se refiere a cualquiera de los países cuya nacionalidad posean; y no se considerará carente de la protección del país de su nacionalidad a la persona que, sin razón válida derivada de un fundado temor, no se haya acogido a la protección de uno de los países cuya nacionalidad posea.

B. 1) A los fines de la presente Convención, las palabras "acontecimientos ocurridos antes del 1. de enero de 1951", que figuran el artículo 1 de la sección $A$, podrán entenderse como:

a) "Acontecimientos ocurridos antes del 1.ำ de enero de 1951, en Europa", o como

b) "Acontecimientos ocurridos antes del 1.ำ de enero de 1951, en Europa o en otro lugar"; y cada Estado Contratante formulará en el momento de la firma, de la ratificación o de la adhesión, una declaración en que precise el alcance que desea dar a esa expresión, con respecto a las obligaciones asumidas por él en virtud de la presente Convención.

Sin embargo, es necesario tener en cuenta que la Convención y la definición de refugiado incorporada en ella fueron redactadas en el marco de los acontecimientos ocurridos en la segunda guerra mundial, y hoy en día las razones por las que una persona puede sentir fundados temores de persecución trascienden las 
motivaciones de raza, religión, nacionalidad y la pertenencia a determinado grupo social o la expresión de opiniones políticas. Así, los conflictos armados internos, las invasiones extranjeras y las guerras civiles han hecho que hoy en día los criterios para determinar quién tiene la calidad de refugiado sean más amplios, por lo que es urgente realizar una interpretación más realista del artículo $1^{\circ}$ de la Convención de 1951, que permita otorgarle el estatus de refugiado a las personas que se ven obligadas a salir del país por estas nuevas circunstancias que no fueron contempladas cuando se redactó la Convención. La necesidad de tener en cuenta estos criterios ha sido incorporada en algunos instrumentos internacionales que, aunque no tienen carácter universal ni vinculante, son una clara muestra de que hoy en día las condiciones son muy diferentes a las de la posguerra ${ }^{16}$.

Así por ejemplo, el artículo $1^{\text {o }}$ de la Convención de la Organización para la Unidad Africana - OUA, por la que se regulan los aspectos específicos de problemas de los refugiados en África, promulgada en 1969 y que entró en vigor en 1974, el término refugiado se aplica no solo a quienes se encuentren en las condiciones descritas en el artículo 1ํㅡ de la Convención de 1951, sino también a toda persona que, a causa de una agresión exterior, una ocupación o una dominación extranjera, o de acontecimientos que perturben gravemente el orden público en una parte o en la totalidad de su país de origen, o del país de su nacionalidad, se ve obligada a abandonar su residencia habitual para buscar refugio en otro lugar fuera de su país de origen o del país de su nacionalidad.

De igual forma, la Declaración de Cartagena (1984), señala en su conclusión III:

Tercera. Reiterar que, en vista de la experiencia recogida con motivo de la afluencia masiva de refugiados en el área centroamericana, se hace necesario encarar la extensión del concepto de refugiado, teniendo en cuenta, en lo pertinente, y dentro de las características de la situación existente en la región, el precedente de la Convención de la OUA (artículo 1, párrafo 2) y la doctrina utilizada en los informes de la Comisión Interamericana de Derechos Humanos. De este modo, la definición o concepto de refugiado recomendable para su utilización en la región es aquella que además de contener los elementos de la Convención de 1951 y el Protocolo de 1967, considere también como refugiados a las personas que han huido de sus países porque su vida, seguridad o libertad han sido amenazadas por la violencia generalizada, la agresión extranjera, los conflictos internos, la vio-

16 Al respecto ha señalado la ACNUR: En contraste, aquellos hombres, mujeres, niños y niñas que huyen de conflictos armados sin ninguno de los elementos de persecución relacionado a un motivo de la Convención, no son refugiados de acuerdo con el sentido de la Convención de 1951. Sin embargo, podrían calificar para la condición de refugiados con base en la definición ampliada de los instrumentos legales regionales de relevancia y bajo el mandato de protección internacional del ACNUR (ver 1.2.2 y 1.2.4, respectivamente) y/o bajo las leyes del país de acogida (ACNUR, 2005). 
lación masiva de los derechos humanos u otras circunstancias que hayan perturbado gravemente el orden público.

Ahora bien, puede ocurrir que la persecución se origine en individuos o entidades no estatales, caso en el cual los temores del solicitante estarán bien fundados si aquellas no quieren o no pueden brindarle protección efectiva.

Además de determinar quién tiene la calidad de refugiado, la Convención de 1951 también señala los eventos en los que una persona no puede adquirir esa condición, los casos en los que una vez adquirida puede serle revocada y las circunstancias en las que cesa el estatus de refugiado:

a. Casos en los que cesa la condición de refugiado. Se trata de aquellos eventos en los que se otorga el estatus de refugiado, pero la persona deja de serlo por concurrir alguna de las circunstancias contempladas en el literal c) del numeral 2) del artículo 1o de la Convención de 1951:

1) Si se ha acogido de nuevo, voluntariamente, a la protección del país de su nacionalidad, $o$

2) Si, habiendo perdido su nacionalidad, la ha recobrado voluntariamente; 0

3) Si ha adquirido una nueva nacionalidad y disfruta de la protección del país de su nueva nacionalidad; o

4) Si voluntariamente se ha establecido de nuevo en el país que había abandonado o fuera del cual había permanecido por temor de ser perseguida; 0

5) $\mathrm{Si}$, por haber desaparecido las circunstancias en virtud de las cuales fue reconocida como refugiada, no puede continuar negándose a acogerse a la protección del país de su nacionalidad.

Queda entendido, sin embargo, que las disposiciones del presente párrafo no se aplicarán a los refugiados comprendidos en el párrafo 1 de la sección A del presente artículo que puedan invocar, para negarse a acogerse a la protección del país de su nacionalidad, razones imperiosas derivadas de persecuciones anteriores.

6) Si se trata de una persona que no tiene nacionalidad y, por haber desaparecido las circunstancias en virtud de las cuales fue reconocida como refugiada, está en condiciones de regresar al país donde antes tenía su residencia habitual.

Queda entendido, sin embargo, que las disposiciones del presente párrafo no se aplicarán a los refugiados comprendidos en el párrafo 1 de la sección A del presente artículo que puedan invocar, para negarse a acogerse a la protección del país de su nacionalidad, razones imperiosas derivadas de persecuciones anteriores. 
b. Cancelación de la condición de refugiado. Ocurre cuando se invalida el estatuto de refugiado que no debió otorgarse en primer lugar, bien sea porque la persona no se encontraba entre las cláusulas de inclusión o debía aplicársele alguna de las cláusulas de exclusión contempladas en los literales D, E y F del numeral 2 del artículo 1o de la Convención de 1951:

D. Esta Convención no será aplicable a las personas que reciban actualmente protección o asistencia de un órgano u organismo de las Naciones Unidas distinto del Alto Comisionado de las Naciones Unidas para los Refugiados. Cuando esta protección o asistencia haya cesado por cualquier motivo, sin que la suerte de tales personas se haya solucionado definitivamente con arreglo a las resoluciones aprobadas sobre el particular por la Asamblea General de las Naciones Unidas, esas personas tendrán, ipso facto, derecho a los beneficios del régimen de esta Convención.

E. Esta Convención no será aplicable a las personas a quienes las autoridades competentes del país donde hayan fijado su residencia reconozcan los derechos y obligaciones inherentes a la posesión de la nacionalidad de tal país.

F. Las disposiciones de esta Convención no serán aplicables a persona alguna respecto de la cual existan motivos fundados para considerar:

a. Que ha cometido un delito contra la paz, un delito de guerra o un delito contra la humanidad, de los definidos en los instrumentos internacionales elaborados para adoptar disposiciones respecto de tales delitos;

b. Que ha cometido un grave delito común, fuera del país de refugio, antes de ser admitida en él como refugiada;

c. Que se ha hecho culpable de actos contrarios a las finalidades y a los principios de las Naciones Unidas.

c. Revocación. Se da cuando una persona que ha sido válidamente reconocida como refugiada, comete después de su reconocimiento una de las conductas contempladas en el literal F del artículo 1ํ de la Convención.

De igual forma, es preciso aclarar que la condición de combatiente tampoco es compatible con el estatus de refugiado. Sin embargo, no ocurre lo mismo con los ex combatientes, cuyas solicitudes deben estudiarse de manera individualizada ${ }^{17}$.

17 Sobre este aspecto en particular ha manifestado la ACNUR: Cuando un conflicto armado en un país genera una afluencia masiva de refugiados hacia países vecinos u otros países, existe la posibilidad que haya combatientes mezclados con los refugiados. La presunción de elegibilidad para refugiados prima facie no incluye a combatientes. Los combatientes activos -es decir, aquellas personas que siguen estando activas en un conflicto armado- no son 
Ahora bien, la decisión de otorgar el reconocimiento del estatus de refugiado es declarativa, es decir que reconoce y confirma formalmente que el individuo en cuestión es refugiado. Esta declaración, que permite distinguir al refugiado del inmigrante no es meramente formal, pues al adquirir la condición de refugiado, la persona se hace titular de una serie de derechos, siendo el más importante de ellos el de la garantía de no devolución o refoulment, el cual constituye la piedra angular del derecho internacional de los refugiados y se ha convertido en norma de derecho internacional consuetudinario, de manera que es aplicable a aquellos Estados que no son parte de la Convención de 1951 o el Protocolo de $1967^{18}$. No obstante, el reconocimiento formal del estatus de refugiado no es requisito para la aplicación plena de la garantía de no devolución.

En la medida de lo posible la decisión sobre el otorgamiento del estatus de refugiado debe estar precedida de un procedimiento individualizado en el que se estudien a profundidad las circunstancias particulares de cada solicitante. Es decir, que el Estado encargado de determinar si una persona tiene el estatus de refugiado no puede adoptar la decisión correspondiente de manera generalizada o masiva, sino que está en el deber de estudiar cada caso por separado. Sin embargo, cuando se trata de solicitudes masivas el Estado debe presumir la buena fe y la elegibilidad del grupo, como lo ha señalado la ACNUR al referirse a los movimientos humanos que generan los conflictos armados:

Con frecuencia, los conflictos armados en un país causan grandes movimientos de personas hacia países vecinos y cercanos. El país de acogida puede enfrentar situaciones en las que haya combatientes mezclados con los refugiados. Tal y como se mencionó en el reconocimiento de la condición de refugiado en el contexto de afluencias masivas se hace generalmente prima facie para todos los miembros de un grupo, con la presunción de que cumplen con los criterios relevantes de elegibilidad de la definición de refugiado. Esta presunción

elegibles para la protección internacional de refugiado. Las actividades militares son incompatibles con el estatuto de refugiado.

La situación es diferente para los ex combatientes. El hecho de haber tomado parte en las hostilidades no descalifica a una persona para obtener protección internacional de refugiado, aunque los ex combatientes que solicitan asilo deben someterse a un procedimiento para determinar si son civiles o no (ACNUR, 2005).

18 La garantía de no devolución está consagrada en el artículo 33 de la Convención de 1951 en los siguientes términos: Artículo 33. -- Prohibición de expulsión y de devolución ("refoulement")

1. Ningún Estado Contratante podrá, por expulsión o devolución, poner en modo alguno a un refugiado en las fronteras de los territorios donde su vida o su libertad peligre por causa de su raza, religión, nacionalidad, pertenencia a determinado grupo social, o de sus opiniones políticas.

2. Sin embargo, no podrá invocar los beneficios de la presente disposición el refugiado que sea considerado, por razones fundadas, como un peligro para la seguridad del país donde se encuentra, o que, habiendo sido objeto de una condena definitiva por un delito particularmente grave, constituya una amenaza para la comunidad de tal país. 
de elegibilidad prima facie para la condición de refugiado no incluye a los combatientes. (ACNUR, 2005, p. 65)

De igual forma, la Convención es clara al señalar que la entrada de manera ilegal de un refugiado al territorio de un Estado, no debe acarrear sanciones penales, "a condición de que se presente sin demora a las autoridades y alegue causa justificada de su entrada o presencia ilegal" (art. 31).

En conclusión, el llamado hoy en día es a hacer una nueva lectura del artículo 1 o de la Convención de 1951, a través de una interpretación que se ajuste especialmente a la realidad de los países de África y del triángulo de Centroamérica. Lo contrario implicaría dejar sin protección a miles de seres humanos cuyas vidas no solo están en peligro por las circunstancias mencionadas en el artículo $1^{\text {o de }}$ la Convención, sino también por conflictos armados, guerras civiles, alteraciones graves del orden público (como es el caso por ejemplo de El Salvador) o invasiones extranjeras (el caso de Siria). Actualmente estas personas se encuentran en un limbo que les impide acceder a la protección que se deriva del estatus de refugiado, limbo que es aprovechado por muchos países para negarle la entrada de cientos de personas a sus fronteras, al punto que actualmente la Convención en lugar de constituir una garantía de protección para los refugiados se está convirtiendo en un obstáculo para que éstos puedan acceder a sus derechos.

En consecuencia, nuestro deber es superar esta zona gris, a través de una lectura realista de la Convención que desentrañe su espíritu y procure al máximo garantizar los derechos de quienes bajo estas nuevas circunstancias se enfrentan al riesgo de ser perseguidos, como diría Pedro Pablo Delgado Hinostroza (2013), "considerar como ilegal la entrada no autorizada de alguien que enfrenta persecución a lo único que contribuye es a criminalizar la actividad de refugiado y a aumentar su sufrimiento".

\section{Principales casos y estándares desarrollados por el Sistema Interamericano de Derechos Humanos y el Tribunal Europeo de Derechos Humanos, con relación a migrantes y otras personas en el contexto de la movilidad humana}

La amplia discrecionalidad, e incluso en muchos casos arbitrariedad, con la que los Estados han abordado situaciones relativas a personas migrantes ha llevado a que los órganos del Sistema Interamericano de Derechos Humanos se hayan visto abocados a ir desarrollando estándares a través de su jurisprudencia para la protección de los derechos humanos de estas personas y sus familias.

Durante las dos últimas décadas el establecimiento de estándares a través del sistema de peticiones y casos ha sido uno de los principales mecanismos de la 
Comisión y la Corte Interamericana para dar respuesta a las diversas situaciones de vulnerabilidad en las que se encuentran las personas migrantes y las violaciones o vacíos de protección que enfrentan en materia de derechos humanos. Los desarrollos en el Derecho Internacional de los Derechos Humanos, así como la interpretación evolutiva que los órganos del Sistema Interamericano han dado a las normas de derechos humanos han servido para poner límites a la soberanía estatal al momento de abordar cuestiones relativas a migrantes.

A continuación se abordará brevemente la forma en la que las normas del Sistema Interamericano de Derechos Humanos, así como la interpretación que la Comisión y la Corte Interamericana han hecho a las mismas, han servido para el desarrollo de estándares de derechos humanos de migrantes y otras personas en el contexto de la movilidad humana. Se analizarán cuatro casos que han sido resueltos en los últimos años y que han hecho aportes importantes en el desarrollo de estándares. Como toda clasificación, se hace la salvedad de que es subjetiva y limitada, por lo cual como autor de este artículo y excomisionado de la Comisión Interamericana de Derechos Humanos - CIDH asumo la responsabilidad de dejar por fuera los aportes que se han hecho desde el Sistema Interamericano a través de otros múltiples informes de casos, medidas cautelares, sentencias y opiniones consultivas. Finalmente en este texto se abordará un reciente caso del Tribunal Europeo de Derechos Humanos - TEDH.

\section{Caso de personas dominicanas y haitianas expulsadas vs. República Dominicana (Corte IDH, 2014)}

Este caso fue presentado por la Comisión ante la Corte el 12 de julio de 2012. Los hechos se refieren a la detención arbitraria y expulsión sumaria del territorio de República Dominicana hacia Haití del señor Benito Tide Méndez y otras 26 personas (10 adultos y 17 niños y niñas). Las expulsiones sumarias se produjeron durante los últimos años de la década de los noventa y los primeros años del 2000 en un contexto de expulsiones colectivas y masivas que afectaban igualmente a personas dominicanas de ascendencia haitiana, como a personas haitianas en situación migratoria regular e irregular, quienes llevaban largos periodos de tiempo viviendo en la República Dominicana y por ende tenían estrechos vínculos laborales y familiares en dicho país. Las características fenotípicas y el color más oscuro de la piel fueron elementos determinantes al momento de seleccionar a las personas que iban a ser expulsadas, lo que demuestra un patrón de discriminación. Todas las víctimas del caso fueron expulsadas a Haití.

El procedimiento de repatriación vigente al momento de los hechos no se aplicó, sino que se trató de expulsiones de facto, fundadas en prejuicios raciales, sin ningún sustento legal ni revisión administrativa o judicial posterior. No existió 
orden de arresto de autoridad competente ni proceso administrativo o judicial abierto en relación con estas personas. Las víctimas no contaron con asistencia jurídica, ni tuvieron posibilidad de recurrir la decisión adoptada, ni existió una orden de la autoridad competente independiente e imparcial que decidiera su deportación.

Algunas de las víctimas expulsadas eran nacionales dominicanos y poseían la documentación pertinente para acreditar tal calidad. Sin embargo, durante su detención arbitraria y expulsión no tuvieron oportunidad formal para presentar esa documentación. En los casos en que fue presentada, ésta fue destruida por los oficiales dominicanos.

Entre los múltiples derechos analizados por la Corte en su sentencia se pronunció ampliamente sobre las garantías que deben observar los Estados en los procesos que puedan culminar en la expulsión o deportación de una persona. La Corte hizo alusión al elenco de garantías mínimas del debido proceso legal, que se aplica en la determinación de derechos y obligaciones de orden "civil, laboral, fiscal o de cualquier otro carácter", así como a los estándares relacionados con procesos de expulsión, sobre lo cual ha sostenido que "el debido proceso debe ser garantizado a toda persona independientemente del estatus migratorio".

Asimismo, la Corte consideró que un proceso que pueda resultar en la expulsión de un extranjero debe ser individual, de modo que se evalúen las circunstancias personales de cada sujeto y se cumpla con la prohibición de expulsiones colectivas. Igualmente resaltó que en los procesos de expulsión en que se encuentren involucrados niñas y niños el Estado deber observar además las garantías que tienen como objetivo la protección del interés superior de los niñas y niños de modo que cualquier decisión de órgano judicial o administrativo que deba decidir acerca de la separación familiar, en razón de la condición migratoria de uno o ambos progenitores, debe contemplar las circunstancias particulares del caso concreto, garantizando así una decisión individual, toda vez que debe perseguir un fin legítimo de acuerdo con la Convención, ser idónea, necesaria y proporcionada.

En los casos de expulsión el Estado debe observar: a) la historia inmigratoria, el lapso temporal de la estadía y la extensión de los lazos del progenitor y/o de su familia con el país receptor; b) la consideración sobre la nacionalidad, guarda y residencia de los hijos de la persona que se pretende deportar; c) el alcance de la afectación que genera la ruptura familiar debido a la expulsión, incluyendo las personas con quienes vive la niña o el niño, así como el tiempo que la niña o el niño ha permanecido en esta unidad familiar, y d) el alcance de la perturbación en la vida diaria de la niña o del niño si cambiara su situación familiar debido a una medida de expulsión de una persona a cargo de la niña o del niño, de forma tal de ponderar estrictamente dichas circunstancias a la luz del interés superior de la niña o niño en relación con el interés público imperativo que se busca proteger. 
Además, la Corte consideró que el criterio fundamental para determinar el carácter "colectivo" de una expulsión de extranjeros, acto prohibido por el artículo 22.9 (Derecho de Circulación y de Residencia) de la Convención, no es el número de extranjeros objeto de la decisión de expulsión, sino que la misma no se base en un análisis objetivo de las circunstancias individuales de cada extranjero. Asimismo, se refirió a la prohibición de que nadie puede ser expulsado del territorio de que es nacional, establecida en el artículo 22.5 (Derecho de Circulación y de Residencia) de la Convención Americana.

Respecto a las garantías judiciales, la Corte sostuvo que la persona sometida a un proceso de expulsión ha de contar con ciertas garantías mínimas, las cuales no fueron cumplidas en el presente caso:

a) ser informada expresa y formalmente de los cargos en su contra y de los motivos de la expulsión o deportación. Esta notificación debe incluir información sobre sus derechos, tales como: i) la posibilidad de exponer sus razones y oponerse a los cargos en su contra, y ii) la posibilidad de solicitar y recibir asistencia consular, asesoría legal y, de ser el caso, traducción o interpretación; b) en caso de decisión desfavorable, debe tener derecho a someter su caso a revisión ante la autoridad competente y presentarse ante ella para tal fin, y c) ser formal y fehacientemente notificada de la eventual decisión de expulsión, que debe estar debidamente motivada conforme a la ley. (Corte IDH, 2014)

\section{Caso familia Pacheco Tineo vs. Bolivia (Corte IDH, 2013)}

Este caso se refiere a la devolución (deportación/expulsión) de la familia Pacheco Tineo a Perú, como consecuencia del rechazo de la solicitud de reconocimiento del estatuto de refugiados en Bolivia el 24 de febrero de 2001. La familia Pacheco Tineo, compuesta por Rumaldo Juan Pacheco Osco, su esposa, Fredesvinda Tineo Godos y sus tres hijos, ingresó a Bolivia el 19 de febrero de 2001. Las autoridades de Migración tomaron nota de que se encontraban de situación migratoria irregular y dispusieron su expulsión a Perú, país del cual habían huido. Posteriormente, el señor Pacheco solicitó el reconocimiento de la condición de refugiados para todos los miembros de su familia en Bolivia, dado que de ser devueltos a Perú estarían en una situación de riesgo. La solicitud de asilo fue resuelta desfavorablemente en un lapso de horas, de manera sumaria y en violación de las garantías de debido proceso.

Este fue el primer caso en que la Corte Interamericana analizó el alcance y contenido del derecho a buscar y recibir asilo y del principio de no devolución 
(non-refoulement), así como su importancia fundamental para la protección internacional de los refugiados y los solicitantes de asilo. En tal sentido, la Corte estableció que cuando ciertos derechos como la vida o integridad personal de las personas extranjeras estén en riesgo, deberán estar protegidas contra la devolución al Estado en que exista ese riesgo, como una modalidad específica de asilo bajo el artículo 22.8 de la Convención, sin importar su estatuto legal o condición migratoria en el Estado de que se trate, y como un componente integral de la protección internacional de los refugiados, bajo la Convención sobre el Estatuto de Refugiados de 1951 y su Protocolo de 1967.

Esto necesariamente implica que esas personas no pueden ser rechazadas en la frontera o expulsadas sin un análisis adecuado e individualizado de sus peticiones. Antes de realizar una devolución, los Estados deben asegurarse que la persona que solicita asilo se encuentra en la capacidad de acceder a una protección internacional apropiada mediante procedimientos justos y eficientes de asilo en el país a donde se le estaría expulsando. Los Estados también tienen la obligación de no devolver o expulsar a una persona que solicita asilo donde exista la posibilidad de que sufra algún riesgo de persecución o bien a un Estado desde donde el cual puedan ser retornados al país donde sufren dicho riesgo (la llamada "devolución indirecta").

La Corte también consideró que el derecho de buscar y recibir asilo y a no ser devuelto en esas circunstancias, establecidos en el artículo 22.7 y 22.8 de la Convención Americana, leído en conjunto con los artículos 8 y 25 de la misma, garantiza que a la persona solicitante de estatuto de refugiado sea oída por el Estado con las garantías mínimas del debido proceso que deben resguardarse en procedimientos de carácter migratorio, en procedimientos relacionados con una solicitud de reconocimiento del estatuto de refugiado o, en su caso, que puedan derivar en la expulsión o deportación de un solicitante de tal condición o de un refugiado.

En este orden de ideas, la Corte consideró que, de conformidad con las garantías establecidas en los artículos 8, 22.7, 22.8 y 25 de la Convención, y tomando en cuenta las directivas y criterios del Derecho Internacional sobre Refugiados, las personas solicitantes de asilo deben tener acceso a procedimientos para la determinación de tal condición, que permitan un correcto examen de su solicitud, de acuerdo con garantías contenidas en la Convención Americana y en otros instrumentos internacionales que, en casos como el presente, implican las siguientes obligaciones para los Estados:

a) deben garantizarse al solicitante las facilidades necesarias, incluyendo los servicios de un intérprete competente, así como, en su caso, el acceso a asesoría y representación legal, para someter su solicitud ante las autoridades. En este sentido, el solicitante debe 
recibir la orientación necesaria en cuanto al procedimiento que ha de seguirse, en un lenguaje y modo que pueda comprender y, en su caso, se le debe dar la oportunidad de ponerse en contacto con un representante de ACNUR;

b) la solicitud debe examinarse, con objetividad, en el marco del procedimiento establecido al efecto, por una autoridad competente claramente identificada, lo cual requiere la realización de una entrevista personal;

c) las decisiones que se adopten por los órganos competentes deben estar debidamente fundamentadas en forma expresa;

d) con la finalidad de proteger los derechos de los solicitantes que puedan estar en riesgo, el procedimiento de asilo debe respetar en todas sus etapas la protección de los datos del solicitante y de la solicitud y el principio de confidencialidad;

e) si no se reconoce al solicitante la condición de refugiado, se le debe brindar la información sobre como recurrir y concedérsele un plazo razonable para ello, según el sistema vigente, a fin de que se reconsidere formalmente la decisión adoptada, y

f) el recurso de revisión o apelación debe tener efectos suspensivos y debe permitirse al solicitante que permanezca en el país hasta que la autoridad competente adopte la decisión del caso, e inclusive mientras esté pendiente el medio de impugnación, a menos que se demuestre que la solicitud es manifiestamente infundada. (Corte IDH, 2013)

Asimismo, la Corte indicó que independientemente de la posibilidad de revisión, en el marco del derecho a la protección judicial consagrado en el artículo 25 de la Convención Americana, y según las regulaciones propias del ordenamiento jurídico de cada Estado, pueden existir determinados acciones o recursos de carácter judicial, por ejemplo de amparo o de habeas corpus, que sean rápidos, adecuados y efectivos para cuestionar la posible violación de los derechos reconocidos en los artículos 22.7 y 22.8 de en la Convención, o en la Constitución y en la ley de cada Estado. En esos términos, tales recursos pueden ser, en determinadas circunstancias, efectivos para remediar parcial o totalmente la situación violatoria y, en su caso, para reconducir los procedimientos administrativos, lo cual corresponderá ser evaluado en cada caso.

\section{Caso Vélez Loor vs. Panamá (Corte IDH, 2010)}

Este caso hace relación a la detención del señor Jesús Tranquilino Vélez Loor, de nacionalidad ecuatoriana, el 11 de noviembre de 2002 en el Puesto Policial 
de Tupiza, en la Provincia del Darién, República de Panamá, por "no portar la documentación necesaria para permanecer en [dicho] país". Posteriormente, la Directora Nacional de Migración y Naturalización del Ministerio de Gobierno y Justicia dictó la orden de detención 1430, y el señor Vélez Loor fue trasladado a la Cárcel Pública de La Palma. Luego de constatar que el señor Vélez Loor había sido deportado el 18 de septiembre de 1996 de Panamá, se resolvió imponerle "la pena de dos (2) años de prisión en uno de los Centros Penitenciarios del País", por haber infringido las disposiciones del Decreto Ley No. 16 sobre Migración de 30 de junio de 1960. La referida resolución no fue notificada al señor Vélez Loor. El 18 de diciembre de 2002 fue trasladado al Centro Penitenciario La Joyita. Posteriormente, el 8 de septiembre de 2003, la Directora Nacional de Migración resolvió dejar sin efecto la pena impuesta, y el 10 de septiembre de 2003 el señor Vélez Loor fue deportado hacia Ecuador.

En lo que respecta a estándares de derechos humanos para personas migrantes, la importancia de esta sentencia radica en que este es el primer caso en el que la Corte Interamericana establece que la detención migratoria debe estar limitada a aquellas situaciones en las que sea absolutamente necesaria, y de una forma que la restricción a la libertad sea estrictamente proporcional. En tal sentido, la Corte estableció que:

En consecuencia, sin perjuicio de la legalidad de una detención, es necesario en cada caso hacer un análisis de la compatibilidad de la legislación con la Convención en el entendido que esa ley y su aplicación deben respetar los requisitos que a continuación se detallan, a efectos de que la medida privativa de libertad no sea arbitraria: i) que la finalidad de las medidas que priven o restrinjan la libertad sea compatible con la Convención; ii) que las medidas adoptadas sean las idóneas para cumplir con el fin perseguido; iii) que sean necesarias, en el sentido de que sean absolutamente indispensables para conseguir el fin deseado y que no exista una medida menos gravosa respecto al derecho intervenido entre todas aquellas que cuentan con la misma idoneidad para alcanzar el objetivo propuesto, razón por la cual el Tribunal ha señalado que el derecho a la libertad personal supone que toda limitación a éste deba ser excepcional, y iv) que sean medidas que resulten estrictamente proporcionales, de tal forma que el sacrificio inherente a la restricción del derecho a la libertad no resulte exagerado o desmedido frente a las ventajas que se obtienen mediante tal restricción y el cumplimiento de la finalidad perseguida. Cualquier restricción a la libertad que no contenga una motivación suficiente que permita evaluar si se ajusta a las condiciones señaladas será arbitraria y, por tanto, violará el artículo 7.3 de la Convención. (Corte IDH, 2010) 


\section{Caso de Andrea Mortlock vs. Estados Unidos (CIDH, 2008)}

La Comisión Interamericana ha ampliado el umbral del principio y derecho de no devolución, para aplicarlo no solamente a solicitantes de asilo y refugiados, sino a cualquier persona en una situación similar a la de los refugiados, tal como sería el caso de los extranjeros que requieren de protección complementaria ${ }^{19}$. Al hacerlo, la Comisión ha considerado que la deportación de un extranjero podría constituir una violación a otros derechos de dicha persona, tales como la prohibición de a ser sometido a tratos crueles, inhumanos o degradantes; la protección de la vida familiar; entre otros.

La importancia del caso de Andrea Morltlock radica en el hecho de que ejemplifica la forma en que la Comisión, a partir de una interpretación evolutiva, ha ampliado el alcance del principio de no devolución a situaciones donde el derecho a la salud de la persona a ser deportada podría verse afectado, teniendo graves afectaciones para su vida, integridad y salud, hasta el punto de considerarlo una sentencia de muerte. Con base en este razonamiento, la Comisión ha evolucionado en el otorgamiento de medidas cautelares hasta el punto de requerir a los Estados que se abstengan de deportar a migrantes a un país donde su salud podría estar en riesgo.

Este caso hace relación al procedimiento de deportación que se adelantó en contra de la señora Andrea Mortlock, de nacional jamaiquina, de 41 años de edad, quien fue detenida en la cárcel del condado de Passaic, en Patterson, New Jersey. Ella había vivido en los Estados Unidos desde 1979, se le había diagnosticado VIH/SIDA desde 1989 y adolecía de una serie de enfermedades relacionadas graves y potencialmente mortales, como la neuropatía y la emaciación extrema. Los peticionarios alegaron que la señora Mortlock estaba en peligro inminente de deportación a Jamaica y que su vida y la integridad física amenazada, dado que muchas de las drogas que requería para su tratamiento no estaban disponibles en Jamaica. Asimismo, los peticionarios alegaban que las personas con signos visibles de VIH/SIDA en Jamaica no recibían atención médica necesaria, se les negaba el acceso al transporte público y privado e incluso podrían ser víctimas de violencia física. Además, la señora Mortlock no tenía familiares, médicos, amigos o conocidos en Jamaica, ya que toda su familia residía en los Estados Unidos.

19 La protección complementaria, también denominada protección subsidiaria, hace relación a los mecanismos legales destinados a proteger y otorgar dicho estatuto a las personas en necesidad de protección internacional que no cumplen con los requisitos establecidos para que les sea concedido el estatuto de refugiado. Las medidas de protección complementaria permiten regularizar la permanencia de personas que no son reconocidas como refugiados pero cuyo retorno sería contrario a obligaciones generales sobre la no devolución, contenidas en diferentes instrumentos de derechos humanos, tales como la Convención Americana sobre Derechos Humanos. 
En virtud de las consideraciones anteriores, la Comisión otorgó medidas cautelares a favor de la señora Mortlock solicitando a los Estados Unidos que se abstuviesen de deportarla a Jamaica, hasta tanto la Comisión no hubiese examinado su petición, sobre la base de que la deportación de la señora Mortlock haría que una eventual decisión de la Comisión se tornase ineficaz y podría causar daños irreparables a la señora Morlock.

Al decidir el caso de la señora Mortlock, la Comisión concluyó que Estados Unidos no debía deportar a la señora Mortlock a Jamaica, dado que las dificultades extraordinarias que enfrentaría en Jamaica como consecuencia de la deportación equivaldrían a una sentencia de muerte. La Comisión consideró:

Que la prueba adecuada es determinar si el interés humanitario del caso es tan importante que no puede razonablemente ser resistido por las autoridades de un Estado civilizado. Más específicamente, la respuesta es si, por razones humanitarias, la afección médica de una persona es tal que no deba ser expulsada, a menos que pueda demostrarse que los servicios médicos y sociales que innegablemente necesita están efectivamente disponibles en el Estado receptor. Por tanto, el parámetro aplicable consistirá en determinar si la deportación creará penurias extraordinarias a la deportada y su familia, hasta el punto de equivaler a una sentencia de muerte, habida cuenta de dos aspectos fundamentales: la disponibilidad de atención médica en el país receptor; y la disponibilidad de servicios sociales y apoyo, en particular, la presencia de parientes cercanos. (CIDH, 2008)

\section{Caso de N.D. y N.T.c. vs. España (TEDH, 2017)}

Por último, en lo que tiene que ver con el Tribunal Europeo de Derechos Humanos - TEDH, vale la pena destacar el caso N.D. y N.T.c. vs. España, sentencia del 3 de octubre de 2017, donde se abordó el tema de la expulsión de personas mientras atravesaban las vallas de contención fronteriza "operativo de frontera", toda vez que en cuanto pusieron los pies en el suelo fueron detenidos por la guardia civil española, quienes los esposaron y devolvieron a Marruecos, se dijo sobre el particular, en la valoración y la aplicación de la jurisdicción que el TEDH (2017):

Considera sin embargo que no es necesario establecer si la valla fronteriza levantada entre Marruecos y España se sitúa o no en territorio de este último Estado. Se limita a recordar, tal como como ya lo ha dejado asentado en el pasado, que desde el momento en que hay un control sobre los demás, se trata en esos casos de un control de jure ejercido por el Estado en cuestión sobre los individuos afectados (Hirsi Jamaa, anteriormente citada, § 77), es decir de un control efec- 
tivo de las autoridades de éste Estado, ya se encuentren éstas en el interior del territorio del Estado o en sus fronteras terrestres. En opinión del TEDH, desde el momento en que los demandantes descendieron de las vallas fronterizas, se encontraron bajo el control continuo y exclusivo, al menos, de facto, de las autoridades españolas. Ninguna especulación que ataña a las competencias, funciones y actuación de las fuerzas del orden españolas en cuanto a la naturaleza y el fin de su intervención podría llevar al TEDH a otra conclusión.

Y más adelante, en el considerando 83, se concluye:

En lo que respecta a los argumentos del Gobierno relativos a la obligación de España, como Estado soberano, a proteger la frontera frente a intentos de entrada ilegal en su territorio, los demandantes se remiten a las sentencias Hirsi Jamaa y otros (antedicha, § 179) y Sharifi y otros (antedicha, §224), e indican que las dificultades en la gestión de los flujos migratorios o en la acogida de los demandantes de asilo no pueden justificar el recurso, por parte de los Estados, a unas prácticas incompatibles con sus obligaciones convencionales. (TEDH, 2017)

Y por último, en lo que concierne a la expulsión colectiva, se dice:

El TEDH recuerda que se debe entender por expulsión colectiva toda medida que compele a unos extranjeros, en tanto que grupo, a abandonar un país, salvo en los casos en que tal medida se toma al término y en base a un examen razonable y objetivo de las circunstancias particulares de cada uno de los extranjeros que forman el grupo (ver, en último lugar, Khlaifia y otros c. Italia [GC], no 16483/12, §§ 237 y siguientes, CEDH 2016, con las referencias que figuran en la misma, para el detalle in extenso de estos principios). Las circunstancias que rodean la puesta en práctica de decisiones de expulsión juegan sin embargo un papel en la valoración del respeto del artículo 4 del Protocolo n o 4 (Georgia c. Rusia (I), antedicha, § 167). (TEDH, 2017)

\section{Conclusiones y recomendaciones}

En conclusión, las crisis migratorias que hemos presenciado en la región demuestran que todavía hay un gran camino por avanzar en lo que respecta al goce efectivo de los derechos humanos de los migrantes y sus familias. Si bien el Derecho Internacional de los Derechos Humanos establece derechos respecto de todas las personas, sin distinción de su nacionalidad, situación de apátrida o situación migratoria, la realidad nos demuestra que en la práctica las personas migrantes siguen quedándose al margen de los derechos humanos. 
Nos encontramos en un momento crítico como región en lo que respecta a la protección de los derechos humanos de las personas migrantes. Las políticas implementadas por algunos Estados de la región son una clara muestra de ello, a través de interceptaciones, deportaciones sumarias y el uso generalizado de la detención migratoria. Al mismo tiempo, los factores generadores de la migración forzada en la región siguen sin ser resueltos en los países del Triángulo Norte y México. A la vez que nos enfrentamos a las situaciones desesperadas de decenas de miles de personas que se están viendo forzadas a migrar de países como Haití, Venezuela o Cuba como una forma para sobrevivir y en cuyo camino se encuentran con personas de África y Asia en situaciones similares o peores. 0, por ejemplo, la situación de decenas de miles de personas que se han visto forzadas a desplazarse como consecuencia de los desastres ocasionados por el Huracán Matthew en Haití. Es muy probable que muchas de las medidas que implementen los Estados con relación a las personas que integran estos flujos migratorios, terminen vulnerando sus derechos humanos antes que protegerlos.

En este sentido, una de las principales acciones que han venido llevando a cabo los órganos del Sistema Interamericano y el Tribunal Europeo de Derechos Humanos para la protección de los derechos de los migrantes ha sido el desarrollo de estándares en su jurisprudencia, en sus informes de casos y en sus sentencias. Nuestro desafío ahora es lograr que esos estándares sean incorporados en las legislaciones nacionales, que se reflejen en las prácticas de los funcionarios migratorios y en la labor jurisdiccional de los jueces y cortes nacionales.

Para tal efecto, es necesario que trabajemos más en promover espacios de formación e incidencia con funcionarios públicos en todos los niveles y de todas las áreas, administrativos, legislativos, judiciales y de organismos autónomos de derechos humanos. Muchas veces el principal problema para migrantes y refugiados está en el primer contacto con las autoridades migratorias o fronterizas, quienes en muchos casos desconocen todas las salvaguardas y garantías que deben observarse respecto de estas personas.

Por último, el acceso a la justicia y a la protección judicial efectiva sigue siendo una asignatura pendiente en muchos países de la región y en particular respecto de este tipo de procedimientos. Desde los órganos del Sistema Interamericano se ha venido intentando llenar estos vacíos de protección a través del desarrollo de la jurisprudencia. Sin embargo, algo que puede contribuir de forma sustancial en este sentido tiene que ver con un mayor litigio de situaciones relativas a violaciones a derechos humanos de personas migrantes e impulsar el litigio estratégico en la materia a nivel nacional, regional e internacional.

Termino evocando el pensamiento esclarecedor de Zygmunt Bauman (2016), en el texto Extraños llamando a la puerta, cuando, citando a Kant con su genialidad, sustituye la hostilidad por el principio de la hospitalidad, en su tercer artículo 
hacía la paz perpetua y en la advocación de que seguimos demorándonos, 200 años después, en atender el llamado kantiano a la hospitalidad.

(...) Kant hace hincapié en que el tema del que escribe y lo que él escribe sobre él es una cuestión...

...no de filantropía, sino de derecho, y ahí la hospitalidad significa el derecho de un extranjero de no ser tratado con enemistad a su llegada a territorio foráneo. Este puede rechazar al extranjero si esto puede suceder sin la ruina de aquel, pero mientras el extranjero esté en su sitio pacíficamente, no puede el otro comportarse hostilmente. No puede apelar a un derecho del huésped (para lo que sería necesario un contrato especialmente bondadoso que lo convirtiera en huésped por cierto tiempo), sino a un derecho de visita, que les corresponde a todos los seres humanos, de ofrecerse a la sociedad en virtud del derecho de propiedad común de la superficie de la Tierra, sobre la que los hombres no se pueden extender infinitamente al tratarse de una superficie esférica, teniendo que soportarse finalmente unos a otros, pero no teniendo nadie más derecho de estar en un lugar de la Tierra que cualquier otro.

Y de su brillante pluma Baum concluye:

La humanidad está en crisis y no hay otra manera de salir de esa crisis que mediante la solidaridad entre los seres humanos. El primer obstáculo en ese camino de salida del alejamiento mutuo es la negativa a dialogar: el silencio nacido de la autoexclusión, de la actitud distante, del desinterés, de la desatención y, en definitiva, de la indiferencia. La dialéctica del trazado de fronteras no debe concebirse como una díada de amor y odio, sino más bien en términos de una tríada: la del amor, el odio y la indiferencia o el abandono.

El compromiso de los Estados no es solo jurídico, es moral, ético y global frente a un asunto, que no es de México ni de Colombia, ni de país alguno individualmente considerado, el compromiso es de la humanidad. Veo cierta frialdad o indiferencia en la Organización de las Naciones Unidas - ONU y en la humanidad en general, frente a una crisis mundial que requiere una respuesta universal.

Así como se ha hecho un Plan Marshall, una Alianza para el Progreso, etc., es un imperativo tomar acciones frente a un mundo globalizado donde se habla de una ciudadanía universal y donde las fronteras están desapareciendo y de hecho ya desaparecieron frente al libre tránsito de mercancías. ¿Es acaso una paradoja o una macabra ironía que se limite la movilidad de los humanos y se potencialice el tránsito libre de las cosas? 


\section{Referencias}

Alto Comisionado de las Naciones Unidas para los refugiados - ACNUR. (2005). La determinación del estatuto de refugiado. 1 de septiembre de 2005. Ginebra.

Alto Comisionado de las Naciones Unidas para los refugiados - ACNUR. (2006). El derecho de asilo y el mandato de la ACNUR. 4 de abril de 2006. Ginebra.

Alto Comisionado de las Naciones Unidas para los refugiados - ACNUR. (2016). Tendencias globales desplazamiento forzado en 2015. Forzados a huir. Ginebra.

Asamblea General de la Organización de las Naciones Unidad - ONU. (1948). Declaración Universal de los Derechos Humanos. París. Recuperado de: http://www.un.org/ en/universal-declaration-human-rights/

Bauman, Z. (2016). Extraños llamando a la puerta. España: Ediciones Paidós

Coloquio de Cartagena. (22 de noviembre de 1984). Declaración de Cartagena sobre Refugiados.

Comisión Interamericana de Derechos Humanos - CIDH. (2008). Informe de Admisibilidady Fondo No. 63/08, caso 12.534, Andrea Mortlock (Estados Unidos). 25 de julio de 2008.

Comisión Interamericana de Derechos Humanos - CIDH. (2015). Refugiados y migrantes en Estados Unidos: familias y niños no acompañados. Doc. 16. 24 julio 2015.

Corte Interamericana de Derechos Humanos - Corte IDH. (2003). Condición jurídica y derechos de los migrantes indocumentados, Opinión Consultiva OC-18/03 del 17 de septiembre de 2003, solicitada por los Estados Unidos Mexicanos.

Corte Interamericana de Derechos Humanos - Corte IDH. (2005). Caso de las niñas Yean y Bosico vs. República Dominicana. Sentencia del 8 de septiembre de 2005.

Corte Interamericana de Derechos Humanos - Corte IDH. (2010). Caso Vélez Loor vs. Panamá. Sentencia del 23 de noviembre de 2010, de excepciones preliminares, fondo, reparaciones y costas.

Corte Interamericana de Derechos Humanos - Corte IDH. (2012). Caso Nadege Dorzema vs. República Dominicana. Sentencia del 24 de octubre de 2012

Corte Interamericana de Derechos Humanos - Corte IDH. (2013). Caso Pacheco Tineo vs. Bolivia. Sentencia del 25 de noviembre de 2013.

Corte Interamericana de Derechos Humanos - Corte IDH. (2014). Caso Personas haitianas y dominicanas expulsadas vs. República Dominicana. Sentencia del 28 de agosto de 2014.

Corte Interamericana de Derechos Humanos - Corte IDH. (2014a). Derechos y garantías de niñas y niños en el contexto de la migración y/o en necesidad de protección internacional, Opinión Consultiva OC-21/14 del 19 de agosto de 2014, solicitada por la República Argentina, la República Federativa de Brasil, la República de Paraguay y la República Oriental del Uruguay. 
De Sousa Santos, B. (1998). De la mano de Alicia. Lo social y lo político en la postmodernidad. Bogotá D.C.: Siglo del Hombre Editores, Ediciones Uniandes.

Delgado, P. (2013). Apátridas, refugiados y migrantes. El derecho a la libre circulación. Lima: Fondo de Cultura Económica.

Grant S. (2011). The recognition of migrant's rights within the UN human rights system. En M.B. Dembour y T. Kelly. (Eds.). Are human rights for migrants? Critical reflections on the Status of Irregular Migrants in Europe and the United States (p. 25). Londres y Nueva York: Routledge.

Migración Colombia. (2018). Todo lo que quiere saber sobre la migración venezolana y no se lo han contado. Bogotá D.C.

Organización de Estados Americanos - OEA. (1961). Convención sobre el Estatuto de los Refugiados de 1951. 28 de julio de 1951.

Organización de Estados Americanos - OEA. (1969). Convención Americana sobre Derechos Humanos. 22 de noviembre de 1969.

Organización de Naciones Unidas - ONU. (1963). Convención de Viena sobre Relaciones Consulares. 23 de Abril de 1963.

Organización de Naciones Unidas - ONU. (1966). Pacto Internacional de Derechos Civiles y Políticos. 16 de diciembre de 1966. Entró en vigor el 23 de marzo de 1976.

Organización de Naciones Unidas - ONU. (2008). Promoción y Protección de todos los Derechos Humanos, -Civiles, Políticos, Económicos, Sociales-y Culturales Incluido el Derecho al Desarrollo. Grupo de Trabajo sobre la Detención Arbitraria, Informe del Grupo, A/HRC/7/4, 10 de enero de 2008, párr. 53, citado en Caso Loor vs. Panamá

Organización para la Unidad Africana - OUA. (1969). Convención de la OUA por la que se regulan los aspectos específicos de problemas de los refugiados en África. 10 de septiembre de 1969.

Sassen, S. (2013). Inmigrantes y ciudadanos. De las migraciones masivas a la Europa fortaleza. Madrid: Siglo XXI.

Tribunal Europeo de Derechos Humanos - TEDH. (2017). Caso N.D. y N.T. vs. España. Sentencia del 3 de octubre de 2017. 